Çukurova Üniversitesi Mühendislik Mimarlık Fakültesi Dergisi, 35(3), ss. 753-768, Eylül 2020

Cukurova University Journal of the Faculty of Engineering and Architecture, 35(3), pp. 753-768, September 2020

\title{
Türkiye'deki Şirketlerin Müşteri Şikayetlerini Değerlendirme Sistemlerinin Araştırılması ve Analizi
}

\author{
Vedat ÇEKICí ${ }^{* 1}$, Oya Hacire YÜREGíR ${ }^{1}$ \\ ${ }^{\text {IC } C u k u r o v a ~ U ̈ n i v e r s i t e s i, ~ M u ̈ h e n d i s l i k ~ F a k u ̈ l t e s i, ~ E n d u ̈ s t r i ~ M u ̈ h e n d i s l i g ̆ i ~ B o ̈ l u ̈ m u ̈, ~ A d a n a ~}$
}

Geliş tarihi: $30.08 .2020 \quad$ Kabul tarihi: 23.10.2020

\section{$\ddot{\mathbf{O} z}$}

Şirketler, müşterilerini memnun ettiği sürece ürün ve servis sunmaya devam etmektedir. Müşteri memnuniyetini etkileyen en önemli faktörlerden biri de müşteri şikayetlerini çözmektir. Bu çalışmada, anket ile Türkiye'deki şirketlerin müşteri şikayet değerlendirme sistem süreçlerine ait veri toplanmış ve sektör bazında şirketlerin kaç adet şikayet aldığı ve ne kadar sürede çözdüğü gibi sorulara yanıt aranmıştır. Veriler istatistiksel olarak analiz edilerek hipotezlerin testleri ve yorumları gerçekleştirilmiştir. Hipotezlerin testinde Ki-Kare testi, Mann Whitney U Testi, işaret testi ve korelasyon analizi uygulanmıştır. Sonuçlara göre müşteri şikayetini sadece hızlı bir şekilde değerlendirmeye başlamak yeterli değildir, aynı zamanda şikayete hızlı ve doğru çözüm bulmakta önemlidir. Ayrıca, şikayetleri değerlendirmek için sistemde görev alan personelin sürekli eğitilmesinin sağlanması ve müşterilerin şikayet değerlendirme süreçlerine dahil edilmesi gerektiği belirlenmiştir.

Anahtar Kelimeler: Müş̧teri şikayeti, Müşteri memnuniyeti, İstatistiksel analiz, Anket

\section{Investigation and Analysis of Customer Complaints Handling System of the Companies in Turkey}

\begin{abstract}
Companies can offer products and services as long as they satisfy their customers. One of the most significant factors affecting customer satisfaction is to resolve customer complaints. In this study, the survey data was collected related to the customer complaints process evaluation system of Turkish companies and answers were sought for questions such as how many complaints companies received on an industry basis and how long they resolved the complaints. The data was analyzed statistically, and the tests of the hypotheses were carried out. Chi-Square test, Mann Whitney U Test, sign test and correlation analysis were applied for testing hypotheses. According to the results, it is not enough just to start evaluating the customer complaint quickly, it is also very important to get a quick and accurate resolution to the complaint for customer satisfaction. Additionally, it has been found that personnel working in the complaint system should be trained continuously and customers should be involved in the complaint handling processes.
\end{abstract}

Keywords: Customer complaint, Customer satisfaction, Statistical analysis, Survey

\footnotetext{
*Sorumlu yazar (Corresponding author): Vedat ÇEKİCİ, vedat.cekici5@gmail.com
} 


\section{GIiRiş}

Müşteriler satın aldıkları ürün ve servisin kullanışlı olması, bakımının kolay, güvenli ve ekonomik olması, belirlenen garanti süresinden önce sorun yaratmaması, sorun yarattı̆̆ında ise beklenen sürede çözüm bulunması durumunda memnun olmaktadır. Müşteri bu ve benzer özellikleri karşılayan ürün ve servis durumlarında beklentilerine olumlu yanit alarak memnuniyet duymaktadır. Memnun olan müşteri oranını yüksek tutmak şirketlerin var olması için önemlidir. $\mathrm{Bu}$ durum hem ürün-servis satış amacıyla hem de satış sonrasında ürünün şikayetini giderme açısından geçerlidir. Araştırma sonuçlarına göre, memnun olmayan müşteriler aynı şirketten tekrar satın almayı düşünmemektedir. $\mathrm{Bu}$ kapsamda, müşteriyi memnun etmenin bir yolu da şikayetleri çözmektir.

Müşteri memnuniyeti, uzun dönemde şirket için hayati öneme sahiptir [1]. Müşteri memnuniyet seviyelerini geliştirmek, şirket güvenliğini sağlamak için uygun bir seçenektir [1]. Bir seçenek de, müşteri şikayetlerini etkin ve hızlı değerlendirme ile memnun olmayan tüketicileri geri kazanmaktır. Bunun için şikayeti çözmek istemek ve tüketici memnuniyetini yeterli seviyelere çıkarmak esastır [1]. Memnun olan müşteri, firmaya şikayet bildirdikten sonra, şikayetine tatminkar bir çözüm bulunduğunda, memnuniyetsizliğini gidererek yeniden satın almaktadır ve şirkete sadık kalmaktadır. Her ürünservis hatası, müşterinin üreticiye doğrudan şikayet bildirmesine neden olmayabilir. Gerçekte ürün/servis hatalarının $\% 5$ 'ten daha azı müşteri şikayetine neden olmaktadır [1]. Bu şikayetlerin de sadece yarısına yakınına tatminkar çözümler üretilmektedir [1]. Müşteri şikayetini çözmek için doğru yönetim süreçlerinin uygulanması ve yeterli kaynak ayrılması ile şikayetler kısmi olarak çözülmektedir [1]. Müşteri kayılarını karşılayacak geri ödeme, ürün değiştirme veya memnun olmayan müşteriyi ilk karşılayacak personelin eğitimi gibi politikaların etkili olduğu kanıtlanmıştır [1]. Tüketicinin firmaya şikayeti, şirket tarafından değerlendirilmez ve şikayetin tatminkar çözümü gerçekleşmez ise müşterinin kaçma durumu söz konusudur ve müșteri o şirketten tekrar satın almamaktadır. Bu durumda şirket eldeki müşterisini kaçırdığ 1 için yeni müşteri kazanma yolunu seçmek zorunda kalacaktır. Fazla sayıda memnun olmayan müşterisi olan şirketler, etkin bir müşteri şikayet yönetimi uygulayarak bu müşterilerden bir kısmını tekrar kazanma şansına sahip olabilirler.

Araştırmalara göre yeni müşteri kazanmak mevcut müşteriyi elde tutmaktan daha maliyetlidir. Yapılan bir çalışma, firmaların \%47'sinin şikayet e-postalarına yanıt verdiğini ve bu durumun da daha yüksek müşteri memnuniyeti ve satın alma ile sonuçlandığını belirlemiştir. Posta, telefon ve yüz yüze görüşme ile şikayetin ele alınmasının müşteri memnuniyetini artırdığ 1 ve müşteri ile uzun vadeli ilişkiler kurulduğu gösterilmiştir [2].

Müşteri ile uzun vadeli ilişkiler kurmak isteyen işletmeler, müşterilerin şikâyetlerini kolaylıkla yapmaları için çeşitli imkânlar sunmalıdır. İşletmeler kendilerine ulaşan şikâyetleri analiz etmek, değerlendirmek, çözmek ve müşteriye geri bildirim yapmak zorundadır. İşletmeler, müşteri şikâyetlerini, kendileri ve müşterileri açısından fayda sağlayacak şekilde yönetmelidir. Bu süreç, müşterinin hangi beklentiler içerisinde olduğunun işletme tarafından bilinmesini sağlayacaktır. İşletmeler aynı zamanda, ürünlerini geliştirme fikrini, müşteri şikâyetleri ile ortaya çıkarmaktadır. $\mathrm{Bu}$ kapsamda Türkiye'deki şirketlerin sahip oldukları müşteri şikayet değerlendirme sistemlerinin mevcut durumunu belirlemek önem arz etmektedir. Bu amaçla Türkiye'deki şirketlerin sahip oldukları müşteri şikayet değerlendirme sistemlerinin mevcut durumunu, önceliklerini ve sorunlarını belirlemek için anket yolu ile veri toplanmış ve istatistiksel olarak analiz edilmiştir. Şirketlerin sahip olduğu bölümler, şikayet sisteminde yer alması gerekli parametreler ve aktiviteler, şikayetleri değerlendirmek ve çözmek için kullanılan kişi sayısı ve bu kişilerin günlük çalışma zamanı, şirketlerin şikayetleri tüm süreçler dahil ortalama kaç günde çözüp kapattı̆̆ 1 ve şikayetlerin \% kaçını doğru olarak çözdüğü, kök nedenini bulma ekibinin kaç kişiden oluştuğu, kök nedeni bulma süreleri ve kök nedeni ilk seferde doğru bulma yüzdeleri, şirketlere yılda ortalama 
kaç adet şikayet geldiği ve yılda ortalama kaç adet şikayet kapandığı konularında veri toplanmış ve veriler değerlendirilerek şirketlere öneriler sunulmuştur. Bu kapsamda çalışmamızda müşteri şikayet süreçleri ile ilgili olarak belirlediğimiz 7 adet ana hipotez için şirketlerin görüşleri toplanmış ve test edilmiştir. Daha sonra da elde ettiğimiz tüm sonuçlar literatür ile karşılaştırılmıştır.

\section{2. ÖNCEKİ ÇALIŞMALAR}

Geçmişte yapılan çalışmaların ağırlıklı olarak müşteri servis kalite modeli oluşturma ile ilgili olduğu görülmüştür. Servis kalitesine verilen önem sayesinde, model çeşitleri gelişmiş ve literatür sürekli yenilenmiştir. Bu çalışmada Türkiye'deki şirketlerin sahip oldukları şikayet değerlendirme sistemlerine ait süreçlerin mevcut durumunu, önceliklerini ve sorunlarını belirlemek için anket yolu ile veri toplanmış ve analiz edilmiştir.

Mattila ve Mount [3], çalışmalarında, şikayete cevap verme süresinin, e-şikayet memnuniyeti üzerine etkisini araştırmıştır. Sonuçlar, problemi yanıtlamanın müşterinin memnun olarak yeniden satın alma niyetini etkilediğini göstermektedir.

Seth ve Deshmukh [4], çalışmalarında literatürden 19 farklı servis kalite modelini incelemiş, farklı servis modellerinin birbiri ile bağlantısını araştırmış, güçlü ve zayıf yönleri tartışmıştır. Tüm modeller tüketici pazarına veya ön saftaki personelin desteklenmesi noktasına odaklanmıştır.

Kulaklı ve Birgün [5], çalışmalarında müşteri merkezli operasyonel bilgi yönetimi için veri yönetimini araştırmıştır. Araştırma sonucunda, iyileştirme hızının, müşteri elde etme hızından daha yüksek olması gerektiği belirlenmiştir. Çünkü müşteri sayısı artarken, sonradan yapılacak geliştirmelere ayrılacak kaynak fazla olmaktadır.

Demir ve Kırdar [6] tarafından müşteri ilişkileri ve sadakati için şirket tarafından yapılması gerekenler incelenmiştir. Elde edilen sonuçlara göre, gelecek kuşaklara servis sunacak işletmelerin müşterileriyle ilgili veri tabanları geniş olacak ve gelişmiş bilgi teknolojileriyle daha fazla bilgiye ulaşarak müşteri ilişkilerini yönetebileceklerdir.

Chan [7], çalışmasında analitik veri modeli yardımıyla müșteri veri ambarındaki veriler analiz edilmiştir. Sonuçta müşterinin sürece dahil edilerek katma değer yaratmasının önemli bir parametre olduğu ortaya çıkmıştır.

Sharma ve diğerleri [8], çalışmalarında, müşterinin ürünü kullanımı sırasında karşılaştığı problemlerin, garanti kapsamında değerlendirilerek problemin giderilme süreci tespit edilmiştir. Şikayet ortalama ürün performansından önce gelmiş ise memnuniyetsizlik bildireceği için garanti kapsamında değerlendirilecek ve kayıp olarak dikkate alınacaktır. Çalışma sonunda kalite kayıplarını gidermek için, önlemlerin üretim sırasında alınmasının gerektiği belirlenmiştir.

Homburg ve diğerleri [9], araştırmalarında şikayet sistemine ait çerçeve oluşturmayı amaçlamıştır. Sonuçlar, şirketin şikayet değerlendirme tasarımının, o firmayla çalışan şikayetçi müşterilere göre değiştiğini göstermektedir.

Henneberg ve arkadaşları [10], anket ile veri toplayarak, büyük ve küçük şirketlerin müşterilere verdiği değerleri ve şikayetleri hangi yöntemle değerlendirdiği karşılaştırmıştır. Sonuçlara göre, büyük şirketler, müşteri memnuniyeti olarak küçük şirketlerden daha iyi, daha fazla rekabet avantajına sahip ve daha az şikayet ile karşılaşacaktır.

Kayabaşı [11], çalışmasında, lojistik faaliyetlerine yönelik şikâyetleri araştırmıştır. Anket yöntemi ile toplanan veriler analiz edilmiştir. Sonuçlar lojistiğin 7 doğrusu olan doğru ürün, doğru miktarda, doğru müşteriye, uygun koşullarda, uygun maliyette, doğru zamanda ve doğru yerde sağlanması tanımıyla uyumlu olmuştur.

Estelami [1], yaptığı iki çalışmada, çeşitli pazar faktörlerinin şikayetlere olan etkisini incelemiştir. Şikayetine olumlu tepki alan tüketicilerin, şikayet etmeyen veya firma tepkisini olumsuz bulanların aksine, yüksek sadakat gösterdiği belirlenmiştir. Çalışmada, şikayetleri etkili olarak değerlendiren 
firmaların şikayetlerden yararlanarak ürünlerini geliştirme şansını elde ettikleri belirlenmiştir.

Johnson ve Mehra [12], şikayet yönetimi uygulaması gerçekleştirmiş ve müşteri şikayetine hızlı yanıt vermenin, müşteri memnuniyeti için hayati olduğunu ortaya çıkarmıştır.

Davidow [13], müşteri şikayetlerine yanıt verilmesinde, organizasyonların şikayet sonrası müşteri davranışını etkileyen 6 boyut belirtmiş ve deneysel olarak ta test etmiş̧tir. Bunlar, zamanındalık, basitleştirme, hatayı tamir etme, özür dileme, güvenilirlik, dikkatliliktir.

Lee ve arkadaşları [14], müşteri şikayetlerinin akıllı kullanımı için bilgiye dayalı metodoloji ve kendi kendine öğrenme özelliği ile şikayetleri çözmek için işletmelere çözüm sunmuştur.

Faed ve arkadaşları [15], sürücülerden toplanan şikayetleri analiz etmiştir. Analizde, bakış açıları sıralanmış ve müşteriye fayda sağlamak ve verimliliği artırmak için optimize edilmiştir.

Einwiller ve Steilen [16], büyük şirketlerin sosyal medyadaki Facebook ve Twitter sayfalarında yer alan şikayetleri çözmek için çalışma yapmış ve şikayetlerin nasıl ele alındığı analiz edilmiştir. Sonuçlar müşteriye düzeltici çalışma yapmayı, probleme çözüm bulacak biriyle ilişkilendirmeyi ve teşekkür etmeyi içermektedir.

Liu ve Yen [17], büyük veri analizi ile otobüs yolcularının şikayetlerini toplamış ve şikayet yönetim süreçlerini iyileştirmiştir. Geliştirilmiş kamu sektörü yönetimi için sistem önermişlerdir.

Strenitzerová ve Gana [18], Slovak elektronik iletişim pazarında müşteri memnuniyeti için çalışma yapmıştır. Çalışmada müşteri tabanlı kurumsallaşmanın boyutları tanımlanmıştır.

İbiş ve arkadaşları [19], otel işletmelerine yönelik internette yapılan müşteri yorum ve şikâyetlerini incelemiştir. En fazla şikâyetin sunulan yiyecekiçecek ve genel hizmet kalitesi ile ilgili olduğu anlaşılmış ve işletmelere öneriler sunulmuştur.

\section{MATERYAL VE METOT}

\subsection{Materyal}

Türkiye'deki şirketlerde müşteri şikayet değerlendirme sistemleri ile ilgili olarak gerçekleştirdiğimiz anketten elde edilen veriler kullanılarak istatistiksel analiz yapılmıştır.

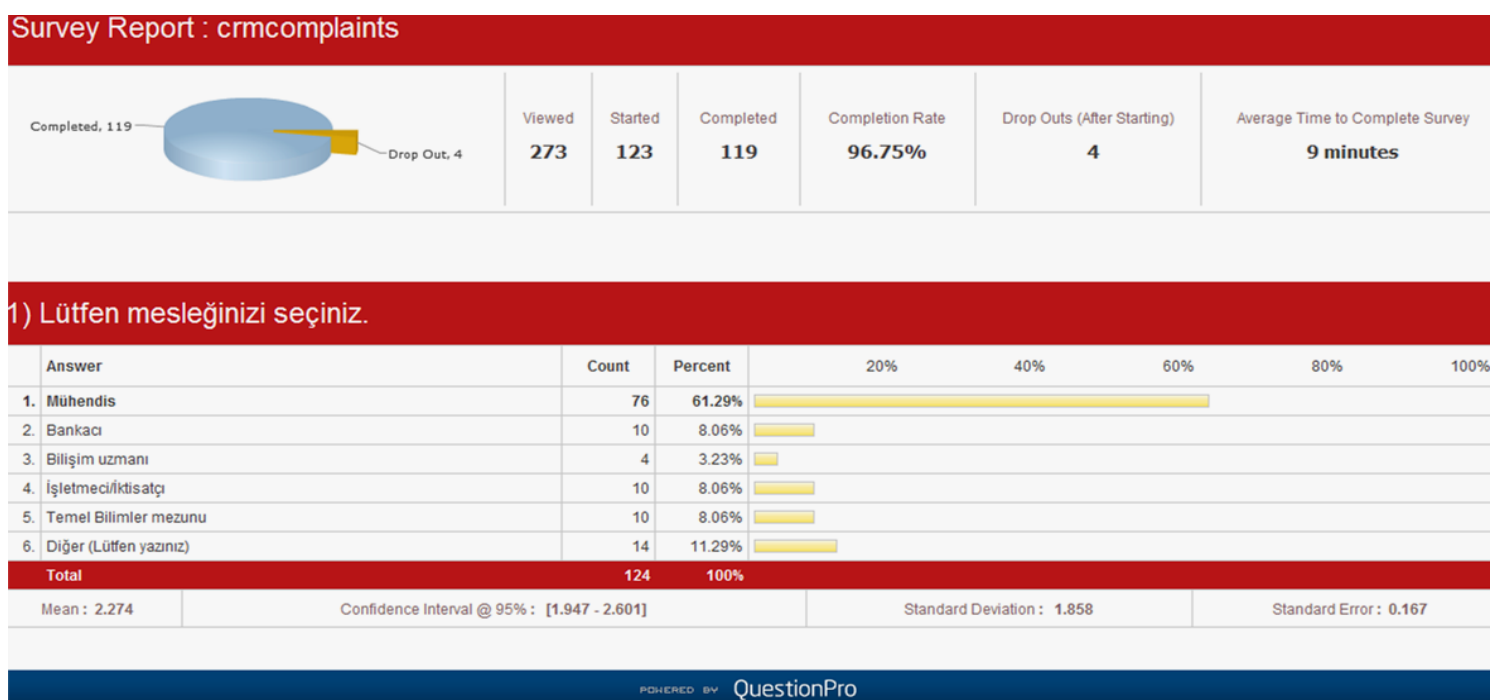

Şekil 1. Anket yanıtlarını internetten online izleme ekranı 
Anket Türkiye'deki üretim ve servis işletmelerine internet yolu ile gönderilmiş veya yüz yüze görüşerek gerçekleştirilmiştir. Anket internet yolu ile "www.questionpro.com" adresinden 1000 kişiye ulaştırılmış olup 51 kişi tamamlamıştır. Ayrıca, 68 farklı şirketten 68 uzman kişi ile yüzyüze görüşülmüştür. Sonuçlar "www.questionpro.com" adresinden sisteme kaydedilmiştir. Anketi 273 kişi incelemiş, 123 kişi başlamış ve 119 kişi ortalama 9 dakikalık bir sürede yanıtlamıştır. Ankete başlayanların $\% 96,75$ 'i anketi tamamlamıştır (Şekil 1).

\subsection{Metot}

Türkiye'deki şirketlerin müşteri şikayet değerlendirme sistemlerinin incelenmesi için öncelikle literatürde yapılan çalışmalar incelenmiş ve boşluklar tespit edilmiştir. Boşluklara yanıt bulacak şekilde anket maddeleri ve hipotezler belirlenmiştir. Daha sonra anket yolu ile veriler toplanmıştır. Ayrıca, şirketlerin şikayet yönetim uzmanlarıyla yapılan yüz yüze görüşmelerden elde edilen bilgiler SPSS ile istatistiksel olarak analiz edilmiştir. Daha sonra hipotezlerin test edilmesinde Ki-Kare testi, Mann Whitney U Testi, işaret testi ve korelasyon analizi uygulanmıştır.

\subsubsection{Anket Örnek Büyüklüğünün Hesabı}

Araştırmanın geçerliliği için anket geri dönüş sayısı doğru seçilmelidir. Türkiye'deki şirket sayısı (ana kütle) bilinmiyor ve çok büyükse anket geri dönüşs sayısı Eşitlik 1 ile gibi hesaplanır [20].

$\mathrm{n}=\left(\mathrm{t}^{2} * \mathrm{p} * \mathrm{q}\right) / \mathrm{d}^{2}$

n=Anket geri dönüşs sayısı

t: Belirli serbestlik derecesinde ve saptanan yanılma düzeyinde $\mathrm{t}$ tablosundan bulunan teorik değerdir. Örnek alırken \% 95 olasılık düzeyi kabul edildiğinden, çift yönlü $\mathrm{t}$ tablosundan $\% 95$ olasılığa karşılık gelen t değeri 1,96 alınmıştır.

(p) incelenen özelliğin toplumda "yaklaşık" sıklığını gösterir, $(q)=(1-p)$
Formülde örnek büyüklüğünü maksimum yapabilmek için $\mathrm{p}=0,5$ seçilmiştir.

(d) incelenen özelliğin sıklığı olarak bulunması düşünülen değerdeki kabul edilebilir yanılma payıdır. Hata payı d, belirlenen, 0,01'den 0,1'e kadar olan değerdir (Bu çalışmada d değeri 0,10 alınmıştır). 1 nolu formülden $n=96,07$ bulunur.

Fiili anket geri dönüş sayısı 119 adettir. 119 sayısı formülden bulunan 96 sayısından büyük olduğu için anket geri dönüş sayısı yeterlidir.

$\mathrm{N}=$ Ana kütle biliniyorsa ve çok büyük değilse anket geri dönüş sayısı Eşitlik 2 ile hesaplanır [20].

$\left.\mathrm{n}=\left(\mathrm{N} * \mathrm{t}^{2} * \mathrm{p} * \mathrm{q}\right) /\left((\mathrm{N}-1) * \mathrm{~d}^{2}\right)+\left(\mathrm{t}^{2} * \mathrm{p} * \mathrm{q}\right)\right)$

N: Türkiye'deki şirket sayısının $\quad 3.500 .000$ olduğunu kabul edersek (Ana kütle) 2 numaralı formülden $\mathrm{n}=96,03$ bulunur. $\mathrm{Bu}$ sonuca göre 119 olan anket dönüşü sayısı yeterlidir.

\subsection{2. İstatistiksel Analizlerde Kullanılan Testler}

İstatistiksel analizlerde kullanılan testler aşağıda verilmektedir.

1. Ki-Kare Testi: Örnek alınan değerlerin, hipotezdeki esas dağılıma uyup uymadığı ölçülür.

a. Uygunluk testi: Beklenen değer ile gözlenen değer arasındaki uygunluk karşılaştırılır.

b. Homojenlik testi: Birbirinden bağımsız olarak seçilen iki veya daha fazla örneklemin aynı ana kütleden çekilip çekilmediğinin belirlenmesinde kullanılır. Hipotezler:

$\mathrm{H}_{0}$ : Örnekler aynı ana kütleden seçilmiştir.

$\mathrm{H}_{\mathrm{A}}$ : Örnekler aynı ana kütleden seçilmemiştir.

c. Bağımsızlık testi: İki veya daha çok değişken grup arasındaki ilişki incelenir. Değişkenlerin birbirinden bağımsız olup olmadığı araştırılır. Hipotezler:

$\mathrm{H}_{0}$ : Değişkenler birbirinden bağımsızdır.

$\mathrm{H}_{\mathrm{A}}$ : Değişkenler birbirinden bağımsız değildir. 
Ki-kare bağımsızlık testinin yapılabilmesi için, gözlenen sonuçlar gruplanmalıdır. $\mathrm{Bu}$ gruplandirmaya kontenjans tablosu denmektedir. Tabloda değişken sınıflarına ait satır ve sütunlar bulunur. Satır sayısını $r$ ve sütun sayısı c ile tanımlanırsa, $\mathrm{r}$ x c 'lik bir tablo oluşur. Bu tablo ile herhangi bir satırdaki ve sütundaki veri arasındaki ilişki incelenir. Her satır ve sütundaki elemanların beklenen $\left(\mathrm{E}_{\mathrm{i}, \mathrm{j}}\right)$ ve gözlenen frekansları $\left(\mathrm{Q}_{\mathrm{i}, \mathrm{j}}\right)$ karşılaştırılır. Test istatistiğinin hesabında aşağıdaki 3 ve 4 ifadelerinden faydalanılır [21].

$$
\begin{aligned}
& \chi^{2}=\sum_{i=1}^{m} \sum_{j=1}^{n} \frac{\left(O_{i j}-E_{i j}\right)^{2}}{E_{i j}} \\
& v=\text { Serbestlik derecesi } \quad v=(r-1)(c-1)
\end{aligned}
$$

$\mathrm{H}_{0}$ hipotezi ret, $\mathrm{H}_{\mathrm{A}}$ hipotezi kabul edilir ise aşağıdaki 5 ifadesi geçerlidir [21].

$\chi^{2}>\chi_{a ;(\mathrm{r}-1)(\mathrm{c}-1)}^{2}$

$\mathrm{H}_{0}$ hipotezi kabul, $\mathrm{H}_{\mathrm{A}}$ hipotezi ret edilir ise aşağıdaki 6 numaralı ifade geçerlidir [21].

$\chi^{2}<\chi_{a ;(\mathrm{r}-1)(\mathrm{c}-1)}^{2}$

Ankette yer alan herhangi 2 soruya verilen cevapların birbiri ile olan ilişkisinin karşılaştırılması ve birbirinden bağımsız olup olmadığını belirlemek amacıyla kikare testi kullanılmıştır ve anlam düzeyi belirlenmiştir.

2. Spearman Rank Order Korelasyonu: İki sürekli nümerik değişken arasındaki ilişkinin derecesini hesaplamak için kullanılır. Pearson korelasyon katsayısının nonparametrik alternatifidir [21]. Sürekli değişkenler bazı ölçümler sonunda elde edilen verilerin değerlerini alır. Bu nedenle her zaman tam değeri vermezler. Örneğin; şirketlerde çalışan eleman sayısı, şirketlere gelen şikayet sayısı, kapanan şikayet sayısı sürekli değişkendir. Ankette yer alan herhangi 2 soruya verilen cevapların birbiri ile olan ilişkisinin zayıf, orta veya kuvvetli olup olmadığını belirlemek amaciyla Spearman testi kullanılmıştır. Spearman Korelasyon katsayı değerleri Çizelge 1'de verilmiştir.
Çizelge1. Spearman korelasyon katsayıları [22].

\begin{tabular}{|l|l|l|}
\hline Korelasyon & Negatif & Pozitif \\
\hline Düşük & $-0,29$ 'dan $-0,10$ a & 0,10 'dan 0,29 a \\
\hline Orta & $-0,49$ 'dan $-0,30$ a & 0,30 'dan 0,49 a \\
\hline Yüksek & $-0,50$ 'den -1'e & 0,5 'den 1'e \\
\hline
\end{tabular}

3. Mann Whitney U-Testi: Sürekli ölçülen iki bağımsız grup arasındaki farklılıkların testinde kullanılan nonparametrik bir testtir. Student $t$ testinin uygulanamadığı durumlarda $\mathrm{t}$ testinin nonparametrik alternatifi olan Mann Whitney U testi kullanılır. $\mathrm{t}$ testinde iki grubun ortalamaları karşılaştırılır, Mann Whitney $U$ testinde ise grupların medyanları karşılaştırılır. Değişkenlerin iki grup içerisinde değerleri sıralı hale dönüştürülür ve sıralamadaki farklılık incelenir [21]. Ankette yer alan herhangi 2 soruya verilen cevapların birbiri ile olan ilişkisinin istatistiksel olarak anlamlı olup olmadığını belirlemek amacıyla ve student $t$ testi şartları sağlanamadığı için çalışmada nonparametrik bir test olan Mann Whitney U testi kullanılmıştır.

4. İşaret Testi: Parametrik bir test olan tek örneklemde $\mathrm{t}$ testi yapılamadığında bunun yerine alternatif olarak kullanılır. t testindeki varsayımlar karşılanamıyor veya örneklem sayısı az veya normal dağılıma uymuyorsa işaret testi kullanılır.

Parametrik olmayan bir istatistiksel tekniktir, dağılımın ortancasını esas alarak hesaplar, değişkenin gerçek değerlerini dikkate almaz sadece toplum ortalamasından büyük mü küçük mü olduğuna bakar. İşaret testi, düzenlediğimiz anketteki hipotezlere katılanlar ile katılmayanların sayısı arasında anlam açısından fark olup olmadığını belirlemek amacıyla kullanılmıştır. İşaret testine ait formüller aşağıda verilmektedir.

\section{Yöntem:}

$\alpha=$ anlamlılık düzeyi $(0,05), \mathrm{w}_{\alpha / 2}$ ( $\mathrm{t}$ tablosundan bulunur), $\mathrm{n}=$ örneklem sayıs1.

$\mathrm{t}=(1 / 2) *\left(\mathrm{n}+\mathrm{w}_{\alpha / 2}\right) * \mathrm{n}^{1 / 2}$

\section{Yöntem:}

n' $\leq 10$ ise işaret testi değeri $r=n '$ alınır. 
n'=n-1 n=örneklem sayıs1.

n'>10 ise $\mathrm{z}$ hesabı yapılır n'=toplam veri sayıs1 $\mathrm{r}=$ negatif işaretli veri sayısı, ortalamanın altında olan sayılar,

n'=ortalamadan farklı olan sayılardır.

$\mathrm{r}=$ toplum ortalamasından küçük olan sayılardır.

$\mathrm{z}=\left[\left|\mathrm{r}-\left(\mathrm{n}^{\prime} / 2\right)\right|-(1 / 2)\right] /\left[\left(\left(\mathrm{n}^{\prime}\right)^{1 / 2}\right) / 2\right]$

Formülden hesaplanan $\mathrm{z}$ değeri bir teorik dağılım olan $\mathrm{Z}$ dağılımı ile yani normal dağılımla karşılaştırılır. \%5 anlamlılık düzeyinde çift yönlü p değerinin nereye karşılık geldiğini belirlemek için tabloya bakılır, $\mathrm{p}$ değeri 0,05 'ten büyükse $\mathrm{H}_{0}$ sıfır hipotezi kabul edilir [23].

\section{ARAŞTIRMA BULGULARI VE TARTIŞMA}

Anketin hazırlanma amac1: Türkiye'deki şirketlerin sahip oldukları müşteri şikayet değerlendirme sistemlerinin mevcut durumunu belirlemek için veri toplamak ve anketteki hipotezler yardımıyla uzmanların görüşünü değerlendirmektir. Analiz işlemleri öncelikle anket çalışmasına katılanların kişisel bilgileri ve işletmeleriyle ilgili bilgileri içeren tanımlayıcı istatistikleri, ikinci olarak ise hipotez testlerini kapsamaktadir. Hipotezler, 7 adet ana hipotez ve 8 adet yardımcı hipotezden oluşmaktadır.

7 adet ana hipotez aşağıda verilmiştir.

$\mathrm{H}_{1}=$ Müşteri şikayetlerine bulunan kök nedenin doğruluğu şikayet kapatma süresini kisaltmaktadır.

$\mathrm{H}_{2}=$ Müşteri şikayetlerine bulunan çözümün doğruluğu şikayet kapatma süresini kısaltmaktadır.

$\mathrm{H}_{3}=$ Müşteri şikayetlerine çözüm bulan eleman sayısının artırılması, aynı oranda çözüm süresini kısaltmaktadır.

$\mathrm{H}_{4}=$ Müşteri şikayet değerlendirme sürecinde çalışan eleman sayısını artırmak, aynı elemanları fazla saatle çalıștırmaktan daha etkilidir.

$\mathrm{H}_{5}=$ Müşteri şikayetlerini çözen elemanların çizelgeli (günde 4-5 saat) çalışması, sabit sürede (günde 9 saat) çalışmasından daha avantajlidir.

$\mathrm{H}_{6}=$ Bir müşteri şikayet sisteminde, çalışan elemanların sayısı arttırıldığında, artan eleman sayısı oranında, elemanların çalışma saati doluluğu azalmaktadır.

$\mathrm{H}_{7}=$ Müşterinin şikayet yönetim sürecine katılması, şikayetin kapanma süresini kısaltmaktadır.

8 adet yardımcı hipotez aşağıda verilmiştir.

$\mathrm{H}_{8}=$ Şirketlerde çalışan eleman sayısının az veya çok olması ile şirketlerin CRM veri tabanı yazılımına sahip olması arasında bir ilişki yoktur.

$\mathrm{H}_{9}=$ Şirketlerde çalışan eleman sayısının az veya çok olması ile şirketlerde şikayetleri değerlendiren ayrı bir birim olması arasında bir ilişki yoktur.

$\mathrm{H}_{10}=$ Şirketlerin "Müşteri Şikayet Yönetimi" uygulaması ile şirketlerde CRM /Müşteri şikayetlerini değerlendiren ayrı bir birim olması arasında bir ilişki yoktur.

$\mathrm{H}_{11}=$ Şikayetin kök nedeni ilk seferde $\% 85$ ve üzeri oranda doğru bulan şirketlerin aynı zamanda Müşteri Şikayetlerini de \%85 ve üzeri oranda doğru çözmesi arasında anlamlı bir ilişki yoktur.

$\mathrm{H}_{12}=$ İşletmede müşteri şikayet değerlendirme biriminin olması ile yıllık gelen şikayetlerin \%100'ünün kapanması arasında anlamlı bir ilişki yoktur.

$\mathrm{H}_{13}=$ İşletmede şikayet değerlendirme biriminin olması ile yıllık gelen müşteri şikayetlerinin $\% 90$ ve üzeri bir oranda doğru çözülmesi arasında anlamlı bir ilişki yoktur.

$\mathrm{H}_{14}=$ Kalifiye eleman sıkıntısı çeken şirketler ile şirketlerin üretim/servis süreçlerinde daha fazla zaman harcaması arasında anlamlı bir ilişki yoktur.

$\mathrm{H}_{15}=$ Mali kaynak sıkıntısı çeken şirketler ile şirketin ARGE süreçlerinde daha fazla zaman harcaması arasında anlamlı bir ilişki yoktur.

Çalışmamızda konsolide bilgiler inceleneceği için ankete katılan firma isimleri yayınlanmamıştır. Önem sırasının belirlenmesinde beşli Likert ölçeği kullanılmıştır. 1: Katılmıyorum, 2: Az katılıyorum, 
3: Orta derecede katılıyorum, 4: Çoğunlukla katılıyorum, 5: Kesinlikle katılıyorum olarak tanımlanmıştır. 1 ve 2 değerleri katılmıyorum, 4 ve 5 değerleri katılıyorum ve 3 değerini alanların yarısı katılıyorum diğer yarısı da katılmıyorum olarak alınmıştır. Ayrıca üçlü puanlama sisteminde En çok önemli 3 puan, önemli 2 puan ve kısmen önemli 1 puan olarak alınmıştır.

\subsection{Tanımlayıcı İstatistikler}

Ankette yer alan sorulara verilen yanıtlar aşağıda özetlenmiștir. Anketi yanıtlayan 119 kișinin 72'si (\%60,50'si) mühendis, 10'u (\%8,4'ü) bankac1/ sigortacı, 13'ü (\%10,92'si) temel bilimler mezunu, 15'i, (\%12,61'i) işletmeci/iktisatç1, 4'ü (\%3,36's1) bilişim/telekominikasyon uzmanı ve 5'i (\%4,2'si) diğer işaretlenmiştir. Ankete katılanların 87 kişisi erkek, 32 kişisi bayandır. Grafikte ilk sırayı 41 şirket ile otomotiv/otomotiv yan sanayi, daha sonra 12 'şer şirket ile metal ve bilişim almıştır, finans/sigorta 11 şirket, inşaat 8 şirket ve gida 7 şirkettir. Diğer seçeneğini işaretleyenler arasında enerji, çevre, doğrudan satış ve dayanıklı tüketim sektörlerine ait işletmeler bulunmaktadır (Şekil 2).

Yukarıda açıklanan tanımlayıcı istatistikler nitel (kalitatif) ve kesikli verilerdir. Anket verilerinden bazıları ise nicel (kantitatif) ve sürekli değişken sayısal verilerdir. Örneğin şirkete gelen şikayet sayısı, kapanan şikayet sayısı, şikayete çözüm bulma süresi, şikayetin kök nedenini bulma süresi, şikayeti kapatma süresi, şirkette çalışan sayısı, şikayetleri değerlendirmek/ çözmek için kullanılan kişi sayısı ve kişinin günlük çalışma zamanı vs, özellikler nicel ve süreklidir.

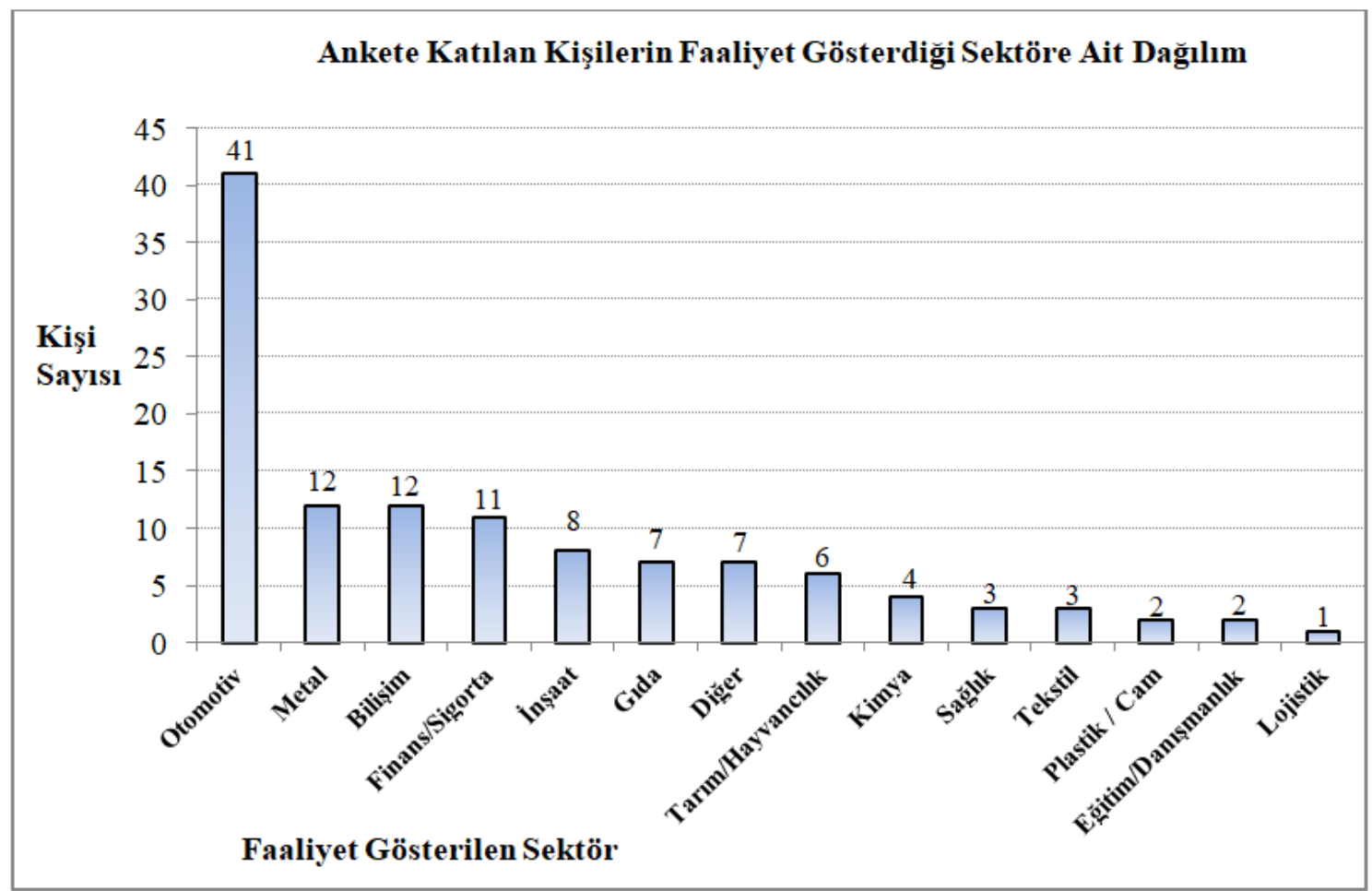

Şekil 2. Ankete katılan şirketlerin faaliyet gösterdiği sektör dağılımı

Ankete katılan işletmelerdeki toplam çalışan sayısına göre şirket oranlarının dağılımı Şekil 3'te verilmektedir. 119 șirketin 44’ü “500 ve üzeri çalışan" sayısına sahiptir. 


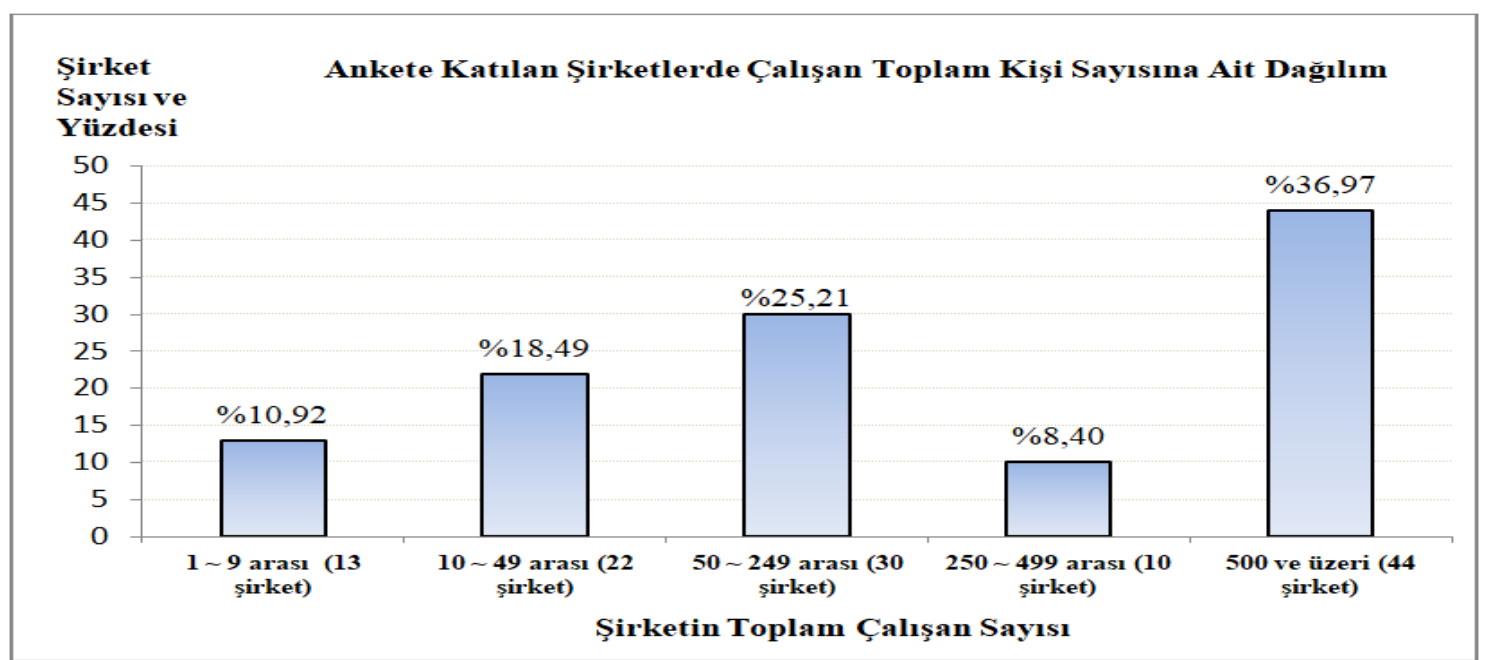

Şekil 3. Şirketlerdeki toplam çalışan sayısına göre şirket oranları

Ankete katılan işletmelerin çoğunda, Satınalma, kalite, üretim/servis, ARGE, süreç iyileştirme, bilişim ve CRM müşteri şikâyetlerini değerlendiren birimler vardır (Şekil 4). En yaygın olan bölüm 109 adet ile Satınalma birimidir. Bazı şirketlerde ARGE, üretim veya bilişim birimi olmasa bile Satınalma birimi bulunabilmektedir. İkinci sırada 106 adet ile üretim/hizmet birimleri, üçüncü sırada 103 adet ile müşteri şikayetlerini değerlendiren birimler yer almaktadır. ARGE çalışması yapan şirketlerin sayısı ise daha azdır.

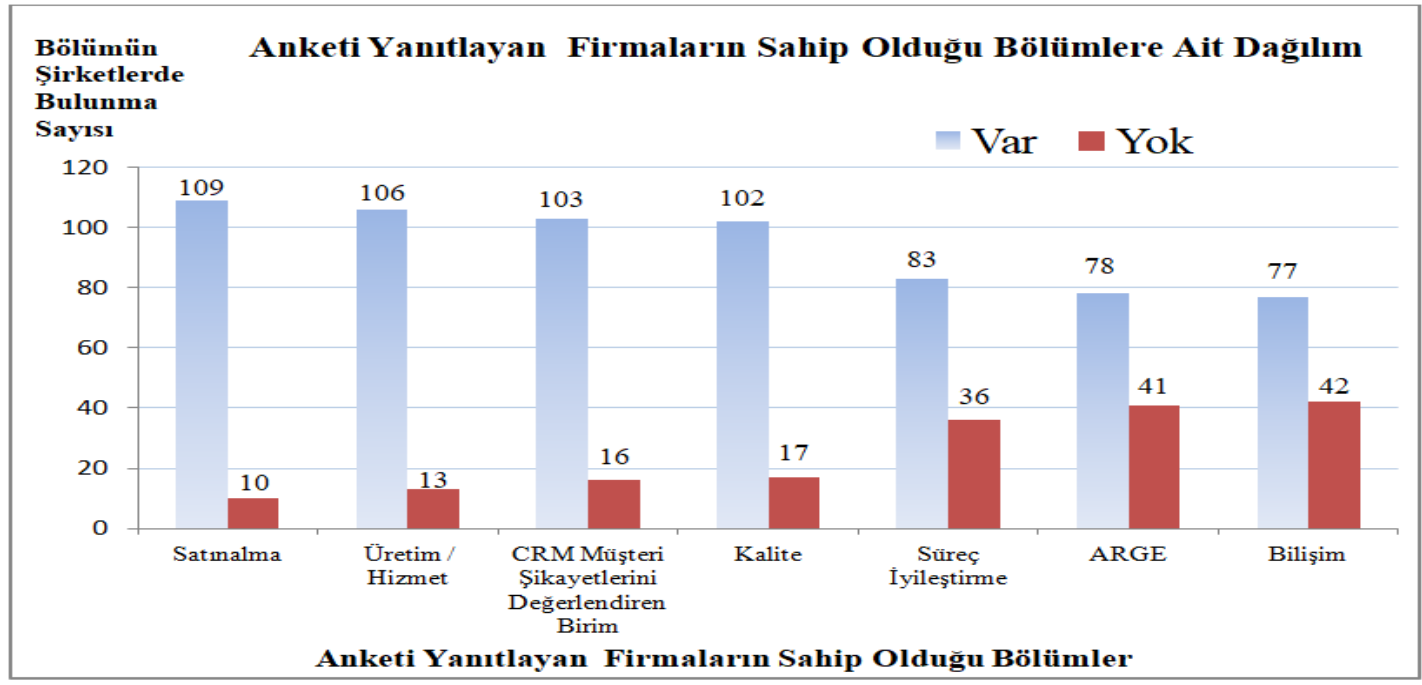

Şekil 4. Ankete katılan şirketlerin sahip olduğu bölümlere ait dağılım

Şikayet sisteminde olması gerekli parametrelerin önem sırasına verilen yanıtlarda, en önemli parametre 198 puanla çözüm bulma hızı, ikinci sırada 160 puanla kök neden bulma hızı olmuştur. Yüz yüze gerçekleştirilen anket görüşmelerinde uzmanlar öncelikle şikayete çözüm bulma hızını öne çıkarmıştır (Şekil 5). Sadece şikayeti hızlı değerlendirmeye başlamak yeterli değildir, aynı anda şikayete hızlı ve doğru çözüm bulmak ta 
önemlidir. Bunun için kalifiye elemanların çözüm bulma ekibine dahil edilmesi önerilmektedir.
Şikayet sisteminde olması gerekli parametrelerin önem sırasının hesabı ise Çizelge 2' de verilmiştir.

Çizelge 2. Şikayet sisteminde olması gerekli parametrelerin önem sırası

\begin{tabular}{|l|c|c|c|c|c|}
\hline $\begin{array}{l}\text { Şikayet sisteminde olması gerekli en } \\
\text { önemli parametre }\end{array}$ & $\begin{array}{c}\text { En Çok Önemli } \\
(3 \text { puan })\end{array}$ & $\begin{array}{c}\text { Önemli } \\
(2 \text { puan })\end{array}$ & $\begin{array}{c}\text { Kismen Önemli } \\
(1 \text { puan })\end{array}$ & $\begin{array}{c}\text { Toplam } \\
\text { Kişi Sayıs1 }\end{array}$ & $\begin{array}{c}\text { Ağırlıklı } \\
\text { Puan }\end{array}$ \\
\hline Çözüm bulma hızı & 35 & 39 & 15 & 89 & 198 \\
\hline Kök neden bulma hızı & 33 & 21 & 19 & 73 & 160 \\
\hline Çözüm bulma hızı & 8 & 32 & 42 & 82 & 130 \\
\hline Şikayeti değerlendirmeye başlama hızı & 29 & 13 & 7 & 49 & 120 \\
\hline Şikayetin kapanma hızı & 12 & 11 & 34 & 57 & 92 \\
\hline
\end{tabular}

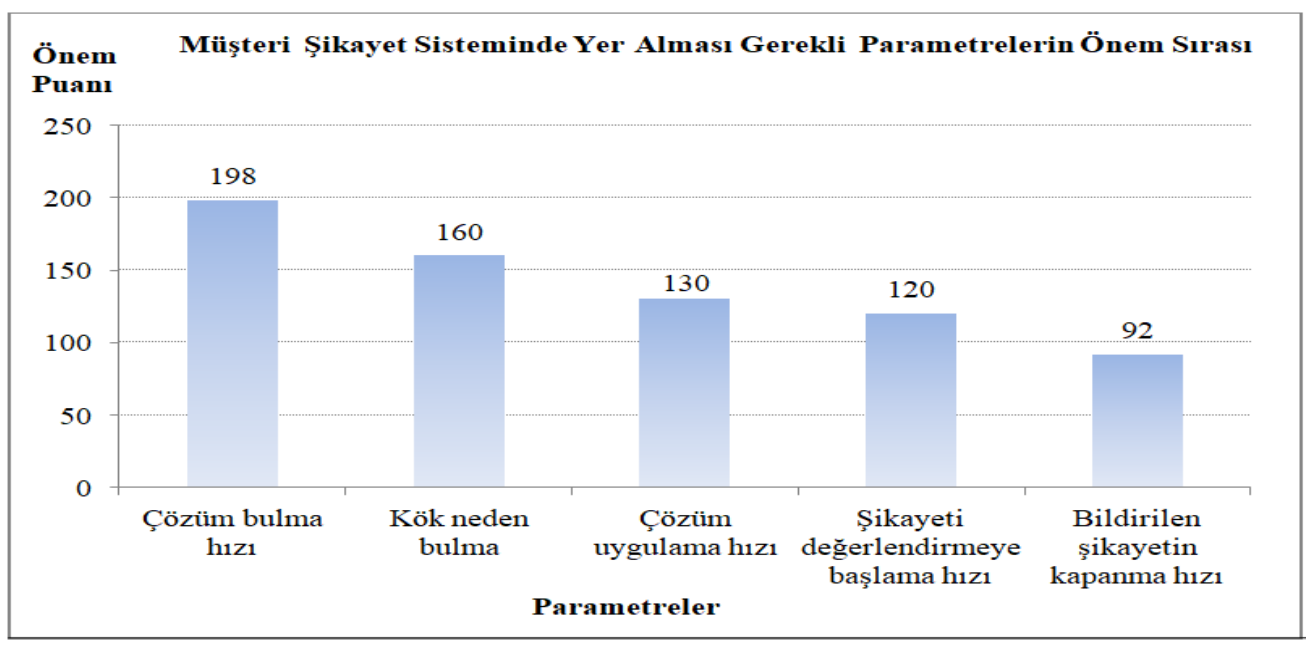

Şekil 5. Şikayet sisteminde olması gerekli parametrelerin önem sırası

"Müşteri şikayet sisteminde gerçekleştirilmesi gerekli önemli aktiviteler nelerdir" sorusuna verilen yanıtlarda CRM elemanlarını eğitmek ve müşterileri çözüme dahil etmek en önemli çıkmıştır (Şekil 6).

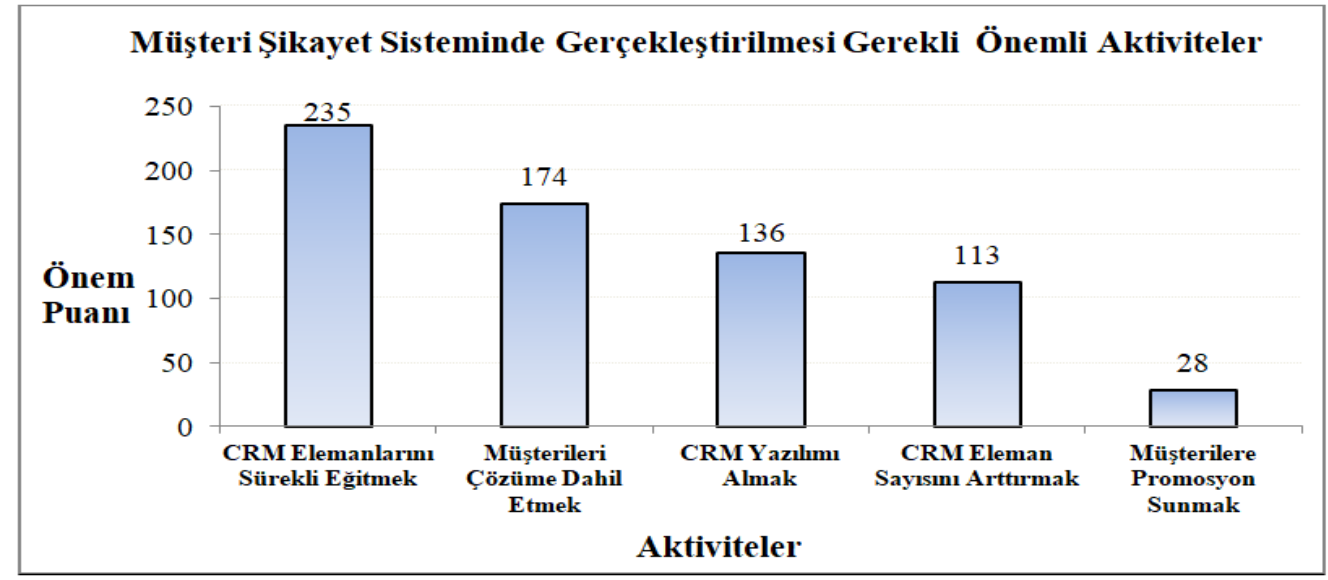

Şekil 6. Şikayet sistemindeki gerekli aktiviteler 


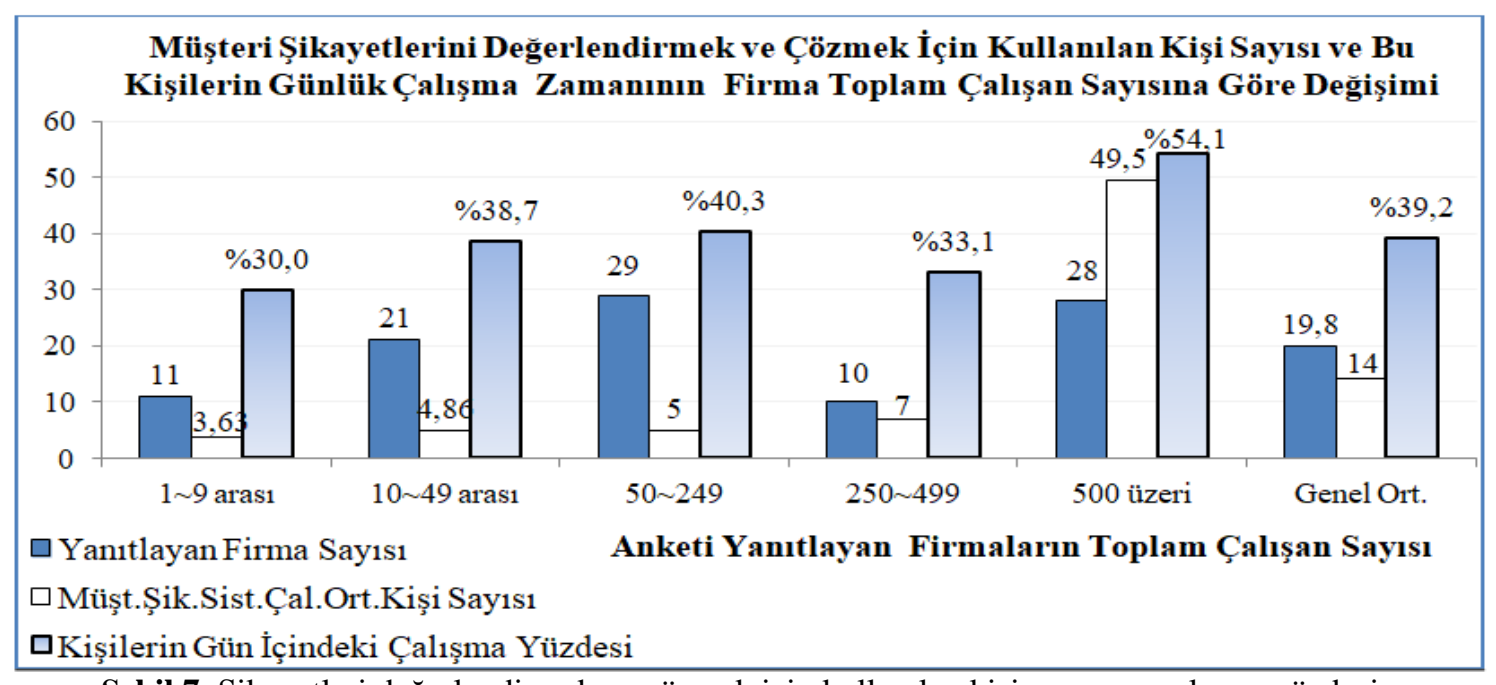

Şekil 7. Şikayetleri değerlendirmek ve çözmek için kullanılan kişi sayısı ve çalışma yüzdesi.

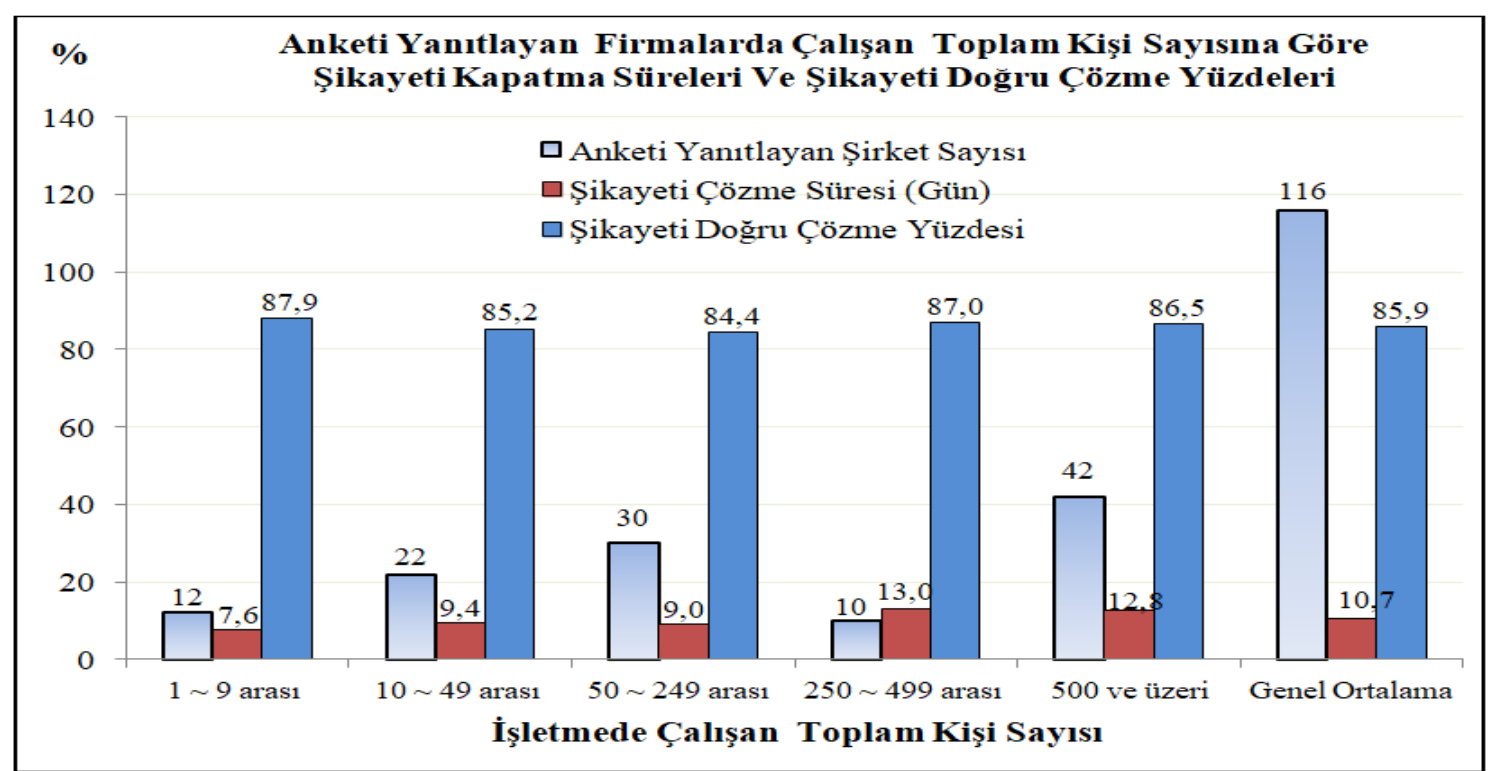

Şekil 8. Firmada çalışan kişi sayısına göre şikayeti kapatma süreleri ve doğru çözme yüzdesi

Şikayetleri çözmek için firmaların toplam kaç kişi çalıştırdıkları ve bu kişilerin mesailerinin yüzde kaçını bu iş için harcadıkları Şekil 7'de verilmiştir. Şirketlerin şikayetleri tüm süreçler dahil ortalama kaç günde çözüp kapattığı ve şikayetlerin yüzde kaçını doğru olarak çözdüğüne ait bilgiler Şekil 8 'de verilmektedir. Şirketlerin şikayetlerin kök nedenini ortalama kaç günde bulduğu, yüzde kaçını ilk seferde doğru bulduğu ise Şekil 9'da verilmiştir. Şikayetlerin kök nedenini bulma süresi ve ilk seferde doğru bulma yüzdesi şikayetin kapanma süresini etkilediği için şirketin kritik başarı faktörleri olarak alınabilir ve hedefler konulabilir. Bazı şirketler ortalama kök neden bulma süresini müşteri beklentisine uygun olarak örneğin en fazla 3 gün ile sinırlayabilir. 


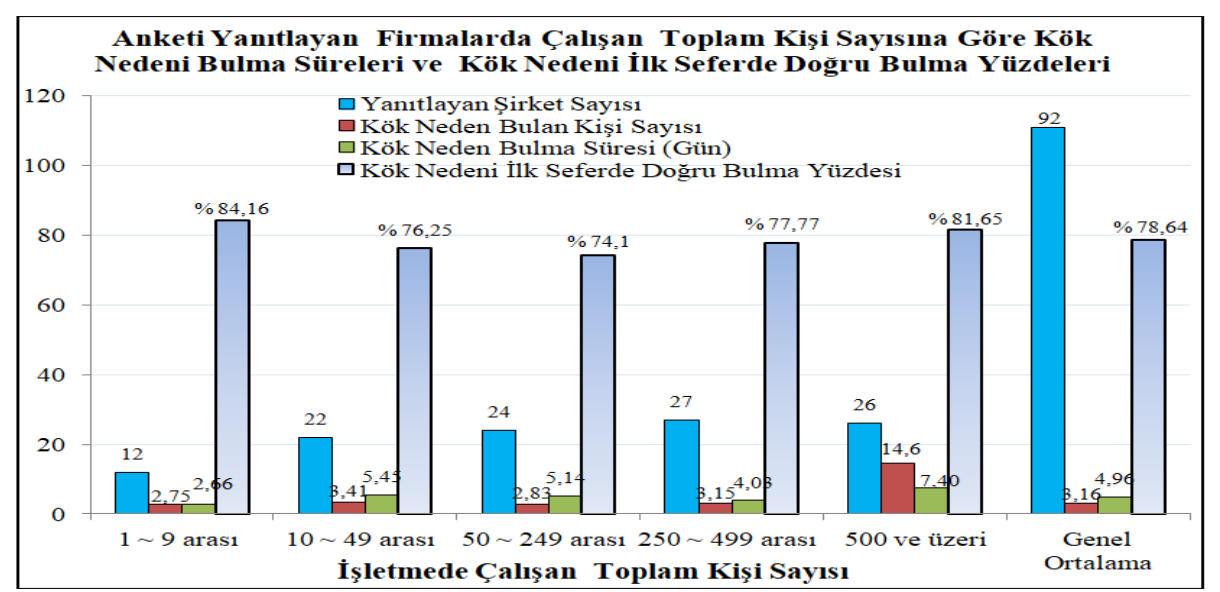

Şekil 9. Firmada çalışan kişi sayısına göre kök neden bulma süresi ve ilk seferde doğru bulma yüzdesi

Şirketlere yılda ortalama kaç adet şikayet geldiği ve kaç adedinin kapandığı Şekil 10'da verilmiştir.

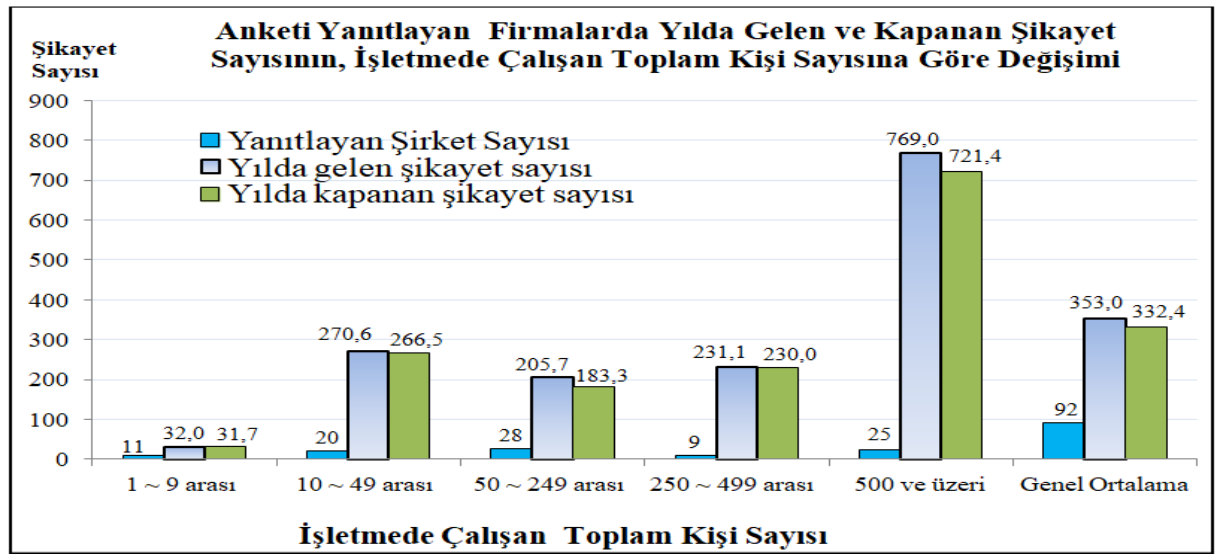

Şekil 10. Firmalara bir yılda gelen/kapanan şikayet sayısının, işletmede çalışan sayısına göre değişimi

\subsection{Temel Hipotezler ve Sonuçları}

Anketteki 7 adet hipotez 1 (en küçük) ile 5 (en büyük) arasındaki puanlar ile değerlendirilmiştir.
Hipotezlerin tamam1 5 üzerinden 3'ü geçmiş ve hipotezlere katılanlar ile katılmayanlar arasında anlamlı bir fark çıkmıştır (Çizelge 3).

Çizelge 3. Hipotezlere verilen yanıtlar

\begin{tabular}{|c|c|c|c|c|c|c|c|c|c|}
\hline & \multicolumn{1}{|c|}{ Issletmelerin hipotezlere verdiği puan } & Ortalama Puan & \multicolumn{2}{c|}{ Cevap say1s1 } & \multicolumn{2}{c|}{ İletmelerin hipotezi kabul durumu } \\
\hline Hipotez & 1 & 2 & 3 & 4 & 5 & ort $_{\text {ort }}$ & n & Kabul & Ret \\
\hline H1 & 9 & 5 & 6 & 22 & 77 & 4,286 & 119 & 102 & 17 \\
\hline H2 & 6 & 4 & 5 & 35 & 69 & 4,319 & 119 & 106 & 13 \\
\hline H3 & 10 & 15 & 38 & 32 & 24 & 3,378 & 119 & 75 & 44 \\
\hline H4 & 13 & 9 & 24 & 34 & 39 & 3,647 & 119 & 85 & 34 \\
\hline H5 & 19 & 15 & 24 & 32 & 29 & 3,311 & 119 & 73 & 46 \\
\hline H6 & 17 & 17 & 21 & 42 & 22 & 3,294 & 119 & 74 & 45 \\
\hline H7 & 12 & 4 & 19 & 36 & 48 & 3,874 & 119 & 93 & 26 \\
\hline
\end{tabular}


Ankette yer alan 7 adet hipotezin yanıtları ile literatür çalışmaları Çizelge 4'de karşılaştırılmıştır.

Çizelge 4. Ankette yer alan ana hipotezlere ait sonuçların literatür ile karşılaştırılması

\begin{tabular}{|c|c|c|c|}
\hline No & HIPOTEZ & $\begin{array}{c}\text { Anket Önem } \\
\text { Puanı }\end{array}$ & LITERATÜRDEKİ BENZER ÇALIŞMALAR \\
\hline 1 & $\begin{array}{l}\mathbf{H}_{1}=\text { "Müşșteri şikayetlerine } \\
\text { bulunan kök nedenin } \\
\text { doğruluğu şikayet kapatma } \\
\text { süresini kısaltmaktadır." }\end{array}$ & $\begin{array}{c}\text { Katılmayan }=17 \\
\text { Katılan }=102 \\
\mathrm{H}_{1}=\text { Kabul } / 4,286\end{array}$ & $\begin{array}{l}\text { 1) Şikayeti değerlendirme hatası, müşteri beklentilerini olumsuz etkilemektedir. Müşteri } \\
\text { şikayetini etkin olarak inceleme ve yanıtlama, müşterinin tekrar satın almasına etkilidir [13]). } \\
\text { 2) Tamir etme, düzeltme, araştırma ve şikayeti ele alma parametreleri, yeniden satın almaya ve } \\
\text { dedikoduya etki etmektedir. Dağıtım, adil değerlendirme, hatayı giderme sonrasındaki } \\
\text { memnuniyeti arttırmaktadır. Sadece özür dilemek etkili değildir Düzeltme ile birlikte } \\
\text { yapılmalıdır. Hızlıca düzeltmek tercih edilir. 4) Problemi ele alma ve yanıtlamanın müşterinin } \\
\text { memnun olarak yeniden satın alma niyetini doğrudan etkilediğini göstermektedir (r =0,77) [13]. } \\
\text { 3) Dikkat, tazminat ödemekten de güçlü etkiye sahiptir. Çözme hızı, müşteriyi sevindirme } \\
\text { açısından ve hayal kırıklığını önleme için anlamlıdır (p=0,08) [1]. }\end{array}$ \\
\hline 2 & $\begin{array}{l}\mathbf{H}_{2}=\text { " Müşteri şikayetlerinde } \\
\text { bulunan çözümün doğruluğu } \\
\text { şikayet kapatma süresini } \\
\text { kısaltmaktadır." }\end{array}$ & $\begin{array}{c}\text { Katılmayan=13 } \\
\text { Kat1lan=106 } \\
\mathrm{H}_{2}=\text { Kabul } / 4,319\end{array}$ & $\begin{array}{l}\text { 1) Açıklama yapmak, tamir etmek ve hızlı çözüm memnuniyet ve yeniden satınalmayı, tamir } \\
\text { etmek, hız ve özür dilemek ise memnuniyet üzerine doğrudan olmayan etkiye sahiptir. Hatayı } \\
\text { giderme hızı ve tamir etme yeniden satın alma oranını arttırmaktadır. Şikayeti gidermek, yeniden } \\
\text { satın almaya pozitif etkimektedir. Şikayete yanıt verme hızı kritik önemdedir [13]. } \\
\text { 2) Şikayete hızlı yanıt vermenin, müşteri memnuniyeti için hayati olduğu ortaya çıkmıştır [12]. }\end{array}$ \\
\hline 3 & $\begin{array}{l}\mathbf{H}_{3}=\text { "Müşteri şikayetlerine } \\
\text { çözzüm bulan kişi sayısının } \\
\text { artırılması, aynı oranda çözüm } \\
\text { süresini kısaltmaktadır." }\end{array}$ & $\begin{array}{c}\text { Kat1lmayan }=44 \\
\text { Katılan }=75 \\
\mathrm{H}_{3}=\text { Kabul } / 3,378\end{array}$ & $\begin{array}{l}\text { 1) Servis iyileştirme stratejisine hızlı bir başlangıç yüksek memnuniyet ile ilişkilidir. Hatayı tamir } \\
\text { etmek ve hatayı çözmek için algılanan hız, memnuniyet üzerine pozitif etkiye sahiptir [13]. } \\
\text { 2) İyileştirme hızının, müşteri elde etme hızından daha yüksek olması gerektiği ortaya çıkmıștır. } \\
\text { Artan müşteri sayısı ile daha sonra yapılacak iyileştirmeler için harcamalar da büyüyecektir [5]. }\end{array}$ \\
\hline 4 & $\begin{array}{l}\mathbf{H}_{4}=\text { "Şikayet sürecinde çalışan } \\
\text { sayısını artırmak, aynı kişilerin } \\
\text { fazla saatle çalışmasından } \\
\text { etkilidir."" }\end{array}$ & $\begin{array}{c}\text { Kat1lmayan }=34 \\
\text { Katılan=85 } \\
\mathrm{H}_{4}=\text { Kabul } / 3,647\end{array}$ & $\begin{array}{l}\text { 1.) Şikayeti çözmek için doğru yönetim süreçlerinin uygulanması ve yeterli kaynak ayrılması ile } \\
\text { şikayet kısmi olarak çözülmektedir [1]). } \\
\text { 2.) Şirketlerinin şikayeti değerlendirmede uygun olmayan enerji ve kaynakların tahsisini önlemek } \\
\text { için uyarlanabilir bir yaklaşım sergilemelidir Homburg ve diğerleri [9]). }\end{array}$ \\
\hline 5 & $\begin{array}{l}\mathbf{H}_{5}=\text { ="Müsşteri şikayetlerini } \\
\text { çözen elemanların çizelgeli } \\
\text { (günde 4-5 saat) çalışması, } \\
\text { sabit sürede (günde 9 saat) } \\
\text { çalışmasından daha } \\
\text { avantajlıdır. " }\end{array}$ & $\begin{array}{c}\text { Kat1lmayan }=46 \\
\text { Katılan=73 } \\
\mathrm{H}_{5}=\text { Kabul } / 3,311\end{array}$ & $\begin{array}{l}\text { 1) Firmalar müşterinin şikayet etmesini kolaylaştırmalı ve telafi etmek için cömert olmalıdır [24]. } \\
\text { 2) Zamanındalık, kolaylaştırma ve tamir etme memnuniyet üzerine olumlu etkimektedir. Ses tonu } \\
\text { ve harekete geçme, müşteri davranışı ve yeniden müşteri olması üzerinde pozitif etkiye sahiptir. } \\
\text { Zamanında davranmamak WOM üzerine negatif etkiye sahiptir [13]. } \\
\text { 3) Şikayet yönetim süreçlerindeki kişilerin günlük çalışma saatlerini arttırmak verimli } \\
\text { olmamaktadır. Fakat toplam çalışma saatleri daha fazla kişiye dağıtıldığında, çözüm süresi, } \\
\text { şikayet kapanma süresi ve kuyrukta bekleme süresi azalmaktadır [25]. }\end{array}$ \\
\hline 6 & $\begin{array}{l}\mathbf{H}_{6}=\text { "Şikayet sistemde. Çalışan } \\
\text { sayısı arttırılırsa, artan sayı } \\
\text { oranında çalışma saati } \\
\text { doluluğu azalmakta." }\end{array}$ & $\begin{array}{c}\text { Katılmayan }=45 \\
\text { Katılan }=74 \\
\mathrm{H}_{6}=\text { Kabul } / 3,294\end{array}$ & $\begin{array}{l}\text { 1) Müşsteri şikayetlerine yanıt vermede, müsșteri davranışlarını etkileyen } 6 \text { boyut vardır, bunlar, } \\
\text { Zamanındalık, Basitleștirme, Tamir etmek, Özür dilemek, Güvenilirlik, Dikkatlilik [13]. } \\
\text { 2) Sistemde çalısşan kişi sayısı azalınca, işgücü kullanım oranı artmaktadır ve şikayet kapanma } \\
\text { süresi uzamaktadır [25]. }\end{array}$ \\
\hline 7 & $\begin{array}{l}\mathbf{H}_{7}=\text { "Müșterinin, şikayet } \\
\text { yönetim sürecine katılması, } \\
\text { şikayetin kapanma süresini } \\
\text { kısaltmaktadır." }\end{array}$ & $\begin{array}{c}\text { Katılmayan=26 } \\
\text { Katılan=93 } \\
\mathrm{H}_{7}=\text { Kabul } / 3,874\end{array}$ & $\begin{array}{l}\text { 1) Bir şirketin şikayet değerlendirme tasarımının, önemli ölçüde o firmayla çalışan şikayetçi } \\
\text { müşterilerin özelliklerine göre değişmektedir [9]. } \\
\text { 2) Müşterilerin üretim sürecine dahil edilerek katma değer yaratmasının müşteri şikayetini } \\
\text { önlemede çok önemli bir parametre olduğu ortaya çıkmıştır [7]. } \\
\text { 3) Şirketler etkili müşteri kazanma sistemi kurmalıdır. İnternet bankacilığı servis kalite } \\
\text { modelinde, müşteri katılımının servis kalitesi üzerine olumlu etkidiği belirtilmişţi [4]. } \\
\text { 4) Servis kalitesini geliştirmek isteyen bir firmanın, ürün ve servislerini alan dış müşterilerini, } \\
\text { kendisine kazandırmak istediği rakip müşterilerini ve müşterilere servis veren kendi servis } \\
\text { çalışanlarını dinlemesi gerektiği önerilmiştir [26]. } \\
\text { 5) Müşsteri ile konuşma, şikayeti çözme memnuniyet için anlamlıdır, özür dilemek etkili ama } \\
\text { anlamlı değildir. Müşterinin şikayet etmesini cesaretlendirmek, müşterilerin memnuniyetini } \\
\text { arttırmaktadır. Tamir mekanizması kurmak şikayet olasılığı üzerine pozitif etkilidir [13]. }\end{array}$ \\
\hline
\end{tabular}

Anketteki ana hipotezlere katılan ve katılmayan sayısına ait işaret testi sonuçları Çizelge 5'te verilmiştir.

Çizelge 5. Ankette yer alan ana hipotezlere katılan ve katılmayan sayısına ait işaret testlerinin sonuçları

\begin{tabular}{|c|c|c|c|c|}
\hline No & HIPOTEZ & $\begin{array}{c}\begin{array}{c}\text { Anket Sonucu / } 5 \\
\text { Üzerinden Önem } \\
\text { Puanı }\end{array} \\
\end{array}$ & $\begin{array}{c}\text { İşaret Test Sonucu } \\
\text { 1.YÖNTEM ( } t \text { tablosuna } \\
\text { göre) } \\
\end{array}$ & $\begin{array}{c}\text { İşaret Test Sonucu } \\
\text { 2.YÖNTEM (z tablosuna } \\
\text { göre) } \\
\end{array}$ \\
\hline 1 & $\begin{array}{l}\mathrm{H}_{10}=\text { "Müşteri şikayetlerine bulunan kök nedenin doğruluğu } \\
\text { şikayet kapatma süresini kısaltmaktadır, hipotezine katılan } \\
\text { sayısı ile katılmayan sayısı arasında anlamlı bir fark yoktur". } \\
\left(\mathrm{H}_{11}=\text { Anlamlı bir fark vardır). }\right.\end{array}$ & $\begin{array}{c}\text { Katılmayan }=17, \\
\text { Katılan }=102 \\
\alpha=0,05=\mathrm{p} \\
\mathrm{H}_{10}=\text { Ret } / 4,286\end{array}$ & $\begin{array}{l}\mathrm{t}=1 / 2 *(\mathrm{n}+\mathrm{w} \alpha / 2 * \sqrt{\mathrm{n}}) \mathrm{n}=119 \\
\text { formülden } \mathrm{t}=50,55 \text { bulunur. } \\
17 \text { veri }<50,55 \text { formül } \\
\mathrm{H}_{10} \text { Ret edilir. }\end{array}$ & $\begin{array}{l}\mathrm{z}=\left[\left|\mathrm{r}-\left(\mathrm{n}^{\prime} / 2\right)\right|-(1 / 2)\right] / \\
{\left[\left(\sqrt{ } \mathrm{n}^{\prime}\right) / 2\right] \text { formülden hesaplanan }} \\
\mathrm{z}=7,6 \text { için } \mathrm{z} \text { tablosundan } \mathrm{p}=0 \\
\text { bulunur. } \mathrm{H}_{10} \text { Ret edilir. }\end{array}$ \\
\hline 2 & $\begin{array}{l}\mathrm{H}_{20}=\text { "Müşteri şikayetlerine bulunan çözümün doğruluğu } \\
\text { şikayet kapatma süresini kısaltmaktadır, hipotezine katılan } \\
\text { sayısı ile katılmayan sayısı arasında anlamlı bir fark yoktur". } \\
\left(\mathrm{H}_{21}=\text { Anlamlı bir fark vardır). }\right.\end{array}$ & $\begin{array}{c}\text { Katılmayan }=13 \\
\text { Katılan }=106 \\
\alpha=0,05=\mathrm{p} \\
\mathrm{H}_{20}=\text { Ret } / 4,319 \\
\end{array}$ & $\begin{array}{l}\text { Formülden } \mathrm{t}=50,55 \text { bulunur. } \\
\mathrm{n}=119 \\
13 \text { veri }<50,55 \text { formül } \\
\mathrm{H}_{20} \text { Ret edilir. }\end{array}$ & $\begin{array}{l}\text { Formülünden hesaplanan } \mathrm{z}=8,37 \\
\text { için } \mathrm{z} \text { tablosundan } \mathrm{p}=0 \text { bulunur. } \\
\mathrm{H}_{20} \text { Ret edilir. }\end{array}$ \\
\hline 3 & $\begin{array}{l}\mathrm{H}_{30}=\text { "Müşteri şikayetlerine çözüm bulan eleman sayısının } \\
\text { artırılması, aynı oranda çözüm süresini kısaltmaktadır, } \\
\text { hipotezine katılanların sayısı ile katılmayanların sayısı } \\
\text { arasında anlamlı bir fark yoktur". ( } \mathrm{H}_{31}=\text { Anlamlı fark vardır). }\end{array}$ & $\begin{array}{c}\text { Katılmayan }=44 \\
\text { Katılan }=75 \\
\alpha=0,05=\mathrm{p} \\
\mathrm{H}_{30}=\text { Ret } / 3,378\end{array}$ & $\begin{array}{l}\text { Formülden } \mathrm{t}=50,55 \text { bulunur. } \\
\mathrm{n}=119 \\
44 \text { veri< }<0,55 \text { formül } \\
\mathrm{H}_{30} \text { Ret edilir. }\end{array}$ & $\begin{array}{l}\text { Formülden hesaplanan } \mathrm{z}=2,67 \\
\text { için } \mathrm{z} \text { tablosundan } \mathrm{p}=0,003 \\
\text { bulunur. } \\
\mathrm{H}_{30} \text { Ret edilir. }\end{array}$ \\
\hline
\end{tabular}




\begin{tabular}{|c|c|c|c|c|}
\hline 4 & $\begin{array}{l}\mathrm{H}_{40}=\text { "Müşteri şikayet değerlendirme sürecinde çalışan } \\
\text { eleman sayısını artırmak, aynı elemanları fazla saatle } \\
\text { çalıștırmaktan daha etkilidir, hipotezine katılan sayısı ile } \\
\text { katılmayan sayısı arasında anlamlı bir fark yoktur". }\left(\mathrm{H}_{41}=\right. \\
\text { Anlamlı bir fark vardır). }\end{array}$ & $\begin{array}{c}\text { Katılmayan }=34 \\
\text { Katılan }=85 \\
\alpha=0,05=\mathrm{p} \\
\mathrm{H}_{40}=\operatorname{Ret} / 3,647\end{array}$ & $\begin{array}{l}\text { Formülden } \mathrm{t}=50,55 \text { bulunur. } \\
\mathrm{n}=119 \\
34 \text { veri }<50,55 \text { formül } \\
\mathrm{H}_{40} \text { Ret edilir }\end{array}$ & $\begin{array}{l}\text { Formülden hesaplanan } \mathrm{z}=4,51 \\
\text { için } \mathrm{z} \text { tablosundan } \mathrm{p}=0,00 \\
\text { bulunur. } \\
\mathrm{H}_{40} \text { Ret edilir. }\end{array}$ \\
\hline 5 & $\begin{array}{l}\mathrm{H}_{50}=\text { "Müşteri şikayetlerini çözen elemanların çizelgeli } \\
\text { (günde } 4-5 \text { saat) çalışması, sabit sürede (günde } 9 \text { saat) } \\
\text { çalışmasından daha avantajlıdır, hipotezine katılan sayısı ile } \\
\text { katılmayan sayısı arasında anlamlı bir fark yoktur". ( } \mathrm{H}_{51}= \\
\text { Anlamlı bir fark vardır). }\end{array}$ & $\begin{array}{c}\text { Katılmayan }=46 \\
\begin{array}{c}\text { Katılan }=73 \\
\alpha=0,05=p \\
\mathrm{H}_{50}=\operatorname{Ret} / 3,311\end{array}\end{array}$ & $\begin{array}{l}\text { Formülden } \mathrm{t}=50,55 \text { bulunur. } \\
\mathrm{n}=119 \\
46 \text { veri<50,55 formül } \\
\mathrm{H}_{50} \text { Ret edilir. }\end{array}$ & $\begin{array}{l}\text { Formülden hesaplanan } \mathrm{z}=2,301 \\
\text { için } \mathrm{z} \text { tablosundan } \mathrm{p}=0,0094 \\
\text { bulunur. } \\
\mathrm{H}_{50} \text { Ret edilir. }\end{array}$ \\
\hline 6 & $\begin{array}{l}\mathrm{H}_{60}=\text { "Bir müşteri şikayet sisteminde, çalışan elemanların } \\
\text { sayısı arttırıldığında, artan eleman sayısı oranında, } \\
\text { elemanların çalışma saati doluluğu azalmaktadır, hipotezine } \\
\text { katılan sayısı ile katılıayan sayıs arasında anlamlı bir fark } \\
\text { yoktur". ( } \mathrm{H}_{61}=\text { Anlamlı bir fark vardır). }\end{array}$ & $\begin{array}{c}\text { Kat1lmayan }=45 \\
\text { Katılan }=74 \\
\alpha=0,05=\mathrm{p} \\
\mathrm{H}_{60}=\operatorname{Ret} / 3,294\end{array}$ & $\begin{array}{l}\text { Formülden } \mathrm{t}=50,55 \text { bulunur. } \\
\mathrm{n}=119 \\
45 \text { veri }<50,55 \text { formül } \\
\mathrm{H}_{60} \text { Ret edilir. }\end{array}$ & $\begin{array}{l}\text { Formülden hesaplanan } \mathrm{z}=2,485 \\
\text { için } \mathrm{z} \text { tablosundan } \mathrm{p}=0,0054 \\
\text { bulunur. } \\
\mathrm{H}_{60} \text { Ret edilir. }\end{array}$ \\
\hline 7 & $\begin{array}{l}\mathrm{H}_{70}=\text { "Müşterinin, şikayet yönetim sürecine katılması, } \\
\text { șikayetin kapanma süresini kısaltmaktadır hipotezine katılan } \\
\text { sayısı ile katılmayan sayısı arasında anlamlı bir fark yoktur". } \\
\left(\mathrm{H}_{71}=\text { Anlamlı bir fark vardır). }\right.\end{array}$ & $\begin{array}{c}\text { Kat1lmayan }=26 \\
\text { Katılan }=93 \\
\alpha=0,05=\mathrm{p} \\
\mathrm{H}_{70} \text { Ret } / 3,874\end{array}$ & $\begin{array}{l}\text { Formülden } \mathrm{t}=50,55 \text { bulunur. } \\
\mathrm{n}=119 \\
26 \text { veri }<50,55 \text { formül } \\
\mathrm{H}_{70} \text { Ret edilir. }\end{array}$ & $\begin{array}{l}\text { Formülden hesaplanan } \mathrm{z}=5,98 \\
\text { için z tablosundan } \mathrm{p}=0 \text { bulunur. } \\
\mathrm{H}_{70} \text { Ret edilir. }\end{array}$ \\
\hline
\end{tabular}

Anketten elde edilen diğer 8 adet göstergenin hipotez test sonuçları Çizelge 6'da verilmiştir.

Çizelge 6. Ankette yer alan diğer 8 adet göstergenin hipotez test sonuçları

\begin{tabular}{|c|c|c|c|c|c|}
\hline $\begin{array}{l}\text { HIIPOTEZ / KARŞILASSTIRILAN ANKET } \\
\text { SORULARI }\end{array}$ & $\chi^{2} / \mathrm{df}$ & $\begin{array}{c}\chi^{2} \\
\text { Sonucu }\end{array}$ & $\begin{array}{r}\chi^{2} \text { Anlam } \\
\text { Düzeyi (p) }\end{array}$ & $\begin{array}{l}\text { MAN WHITNEY U Asymp.Sig } \\
\text { (2-tailed) değeri }\end{array}$ & $\begin{array}{l}\text { İlişkinin Gücü / } \\
\text { Spearman Değeri }\end{array}$ \\
\hline $\begin{array}{l}\mathrm{H}_{8}=\text { "SSirketlerde çalışan eleman sayısının az veya çok } \\
\text { olması ile şirketlerin CRM veri tabanı yazılımına sahip } \\
\text { olması arasında bir iliş̧ yoktur". }\end{array}$ & $9,731 / 1$ & Ret & 0,002 & $\begin{array}{l}\text { Ret: Anlamlılık: } 0,002<0,05 \text { sonuç } \\
\text { istatistiksel olarak anlamlıdır ve } \\
\text { zayıf bir ilişki vardır. } Z=-3,106\end{array}$ & Zayif / 0,286 \\
\hline $\begin{array}{l}\mathrm{H}_{9}=\text { "Şirketlerde çalışan eleman sayısının az veya çok } \\
\text { olması ile şirketlerde şikayetleri değerlendiren ayrı bir birim } \\
\text { olması arasında bir ilişki yoktur". }\end{array}$ & $0,011 / 1$ & Kabul & 0,565 & $\begin{array}{c}\text { Kabul: Anlamlılık: } 0,08>0,05 \\
\text { sonuç istatistiksel olarak anlamlı } \\
\text { değildir ve ilișki yoktur. } Z=-1,752\end{array}$ & Zayıf / - 0,010 \\
\hline $\begin{array}{l}\mathrm{H}_{10}=\text { "Şirketlerin “'Sikayet Yönetimi”" uygulaması ile } \\
\text { şrketlerde CRM /Müssteri şikayetlerini değerlendiren ayrı } \\
\text { bir birim olması arasında bir ilișki yoktur". }\end{array}$ & $38,386 / 1$ & Ret & 0,000 & $\begin{array}{l}\text { Ret: Anlamlılık: } 0,0000,000<0,05 \\
\text { sonuç istatistiksel olarak nlamlıdır } \\
\text { ve yüksek bir ilişki vardır. } Z=-6,17\end{array}$ & Yüksek/ 0,568 \\
\hline $\begin{array}{l}\mathrm{H}_{11}=\text { "Şikayetin kök nedeni ilk seferde \% } 85 \text { ve üzeri oranda } \\
\text { doğru bulan şirketlerin aynı zamanda Müşteri Şikayetlerini } \\
\text { de \% } 85 \text { ve üzeri oranda doğru çözmesi arasında anlamlı bir } \\
\text { ilişsi yoktur" bulmaktadır?" karşılaştırılmıştır. }\end{array}$ & $18,278 / 1$ & Ret & 0,000 & $\begin{array}{l}\text { Ret: Anlamlılık: } 0,000<0,05 \text { sonuç } \\
\text { istatistiksel olarak anlamlıdır ve } \\
\text { orta derece ilişsi vardır. } Z=-4,255\end{array}$ & Orta / 0,415 \\
\hline $\begin{array}{l}\mathrm{H}_{12}=\text { =’İşletmede müşteri şikayet değerlendirme biriminin } \\
\text { olması ile yıllık gelen şikayetlerin \% 100' ünün kapanması } \\
\text { arasında anlamlı bir ilişki yoktur". }\end{array}$ & $0,151 / 1$ & Kabul & 0,456 & $\begin{array}{l}\text { Kabul: Anlamlılık: } 0,699>0,05 \\
\text { sonuç istatistiksel olarak anlamlı } \\
\text { değildir, ilişki yoktur. } Z=-0,386\end{array}$ & Zayıf / 0,038 \\
\hline $\begin{array}{l}\mathrm{H}_{13}=\text { " İşletmede şikayet değerlendirme biriminin olması ile } \\
\text { ylllık gelen müşteri şikayetlerinin \% } \% 0 \text { ve üzeri bir oranda } \\
\text { doğru çözülmesi arasında anlamlı bir ilişki yoktur". }\end{array}$ & $0,270 / 1$ & Kabul & 0,401 & $\begin{array}{c}\text { Kabul:Anlamlılık: } 0,605>0,05 \\
\text { sonuç istatistiksel olarak anlamlı } \\
\text { değildir, ilişki yoktur. } Z=-0,518\end{array}$ & Zayıf / 0,048 \\
\hline $\begin{array}{l}\mathrm{H}_{14}=\text { =Kalifiye eleman sıkıntısı çeken şirketler ile şirketin } \\
\text { üretim/servis süreçlerinde daha fazla zaman harcaması } \\
\text { arasında anlamlı bir ilişki yoktur }\end{array}$ & $0,008 / 1$ & Kabul & 0,548 & $\begin{array}{l}\text { Kabul:Anlamlılık: } 0,929>0,05 \\
\text { sonuç istatistiksel olarak anlamlı } \\
\text { değildir, ilişki yoktur. } Z=-0,089\end{array}$ & Zayıf/-0,008 \\
\hline $\begin{array}{l}\mathrm{H}_{15}=\text { ="Mali kaynak sıkıntısı çeken şirketler ile şirketin } \\
\text { ARGE süreçlerinde daha fazla zaman harcaması arasında } \\
\text { anlamlı bir ilişki yoktur". }\end{array}$ & $1,094 / 1$ & Kabul & 0,205 & $\begin{array}{l}\text { Kabul:Anlamlılık: } 0,298>0,05 \\
\text { sonuç istatistiksel olarak anlamlı } \\
\text { değildir, ilişki yoktur. } Z=-1,042\end{array}$ & Zayıf / 0,096 \\
\hline
\end{tabular}

\section{SONUÇLAR VE ÖNERİLER}

Ülkemizdeki şirketlerin müşteri şikayet değerlendirme sistemleri üzerine yapılan bir anketin sonuçları istatistiksel yöntemlerle analiz edilmiştir. Çalışma ile ülkemizdeki şirketlerin müşteri şikayet sistemlerinin seviyesi ölçülmüş ve uluslararası düzeyde karşılaştırmaların daha sağlıklı yapılmasına destek verilmiştir.

Çalışmamızda aşağıdaki sonuçlara ulaşılmıştır.
1) Yüz yüze yapılan anket görüşmelerinde uzmanlar öncelikle şikayete çözüm bulma hızını ön plana çıkarmıştır. Sadece şikayeti ele almaya hızlı başlamak yeterli olmamaktadır, aynı zamanda hızlı çözüm bulmak da önemlidir. Bunu sağlamak için şirketlerin eğitimli ve kalifiye elemanlarını çözüm bulma ekibine dahil etmesi önerilmiştir.

2) Ankete katılan işletmelerin çoğunda, ARGE, Satınalma, kalite, üretim-servis ve şikâyetleri 
değerlendiren birim vardır. En fazla bulunan ise Satınalma bölümüdür.

3) Şikayetleri değerlendirmek için en önemli parametreler olarak CRM elemanlarını eğitmek ve müşterileri çözüme dahil etmek gelmektedir.

4) Kurumsal şirketlerin, müşteri şikayet değerlendirme sistemine atadı ̆ 1 eleman sayısı fazladır ve bu elemanlar çalışma zamanlarının yaklaşık olarak yarısını bu iş için harcamaktadır.

5) Ankete katılan Türkiye'deki şirketler şikayetin kök nedenini ortalama $\sim 5$ günde bulmaktadır.

6) Ankete katılan Türkiye'deki şirketler müşteri şikayetini ortalama $\sim 11$ günde çözmektedir.

7) Çalışan sayısı fazla olan kurumsal şirketler daha fazla şikayet almakta ve şikayeti çözerek müşteriyi memnun etme şansı yakalamaktadır. Bunun nedeni ise kurumsal şirketlerin müşteri şikayet değerlendirme sistemine önem vermesi ve müşteriye şikayetini bildirme için çeşitli kolaylaştırıcı yollar sunmasıdır.

Anket verileri ile oluşturulan yardımcı hipotezler de test edilmiş ve aşağıdaki sonuçlara ulaşılmıştır.

1) Çalışan sayısı fazla olan şirketler çalışan sayısı az olan şirketlere göre, bir miktar daha fazla oranda CRM veritabanı yazılımına sahiptir.

2) Çalışan sayısına bağlı olmaksızın şirketlerde şikayetleri değerlendiren bir birim bulunmaktadır.

3) Şirketlerin "Müşteri Şikayet Yönetimi'" uygulaması ile şirketlerde müşteri şikayetlerini değerlendiren ayrı birim olması arasında pozitif yönde yüksek bir ilişki belirlenmiştir.

4) Şikayetin kök nedenini ilk seferde yüksek oranda doğru bulan şirketlerin aynı anda şikayeti de ilk seferde doğru çözdüğ̈̈ belirlenmiștir.

5) İşletmede ayrı bir şikayet değerlendirme biriminin olması ile yıllık gelen şikayetlerin tamamının kapanması arasında anlamlı bir ilişki belirlenmemiştir. Ayrı bir şikayet değerlendirme birimi olsa da olmasa da şirketler şikayetleri kapatmakta ve büyük oranda doğru çözmektedir.

\section{TEŞEKKÜR}

Çalışmamızı MMF2011D1 nolu proje ile destekleyen Çukurova Üniversitesi Bilimsel Araştırma Projeleri Koordinatörlüğü'ne teşekkürlerimizi sunarız.

\section{KAYNAKLAR}

1. Estelami, H., 2000. The Profit Impact of Consumer Complaint Solicitation Across Market Conditions, Journal of Professional Services Marketing, 20(1), 165- 195.

2. Strauss, J., Hill, D.J. 2001. Consumer Complaints By E-mail: An Exploratory Investigation of Corporate Responses and Customer Reactions. Journal of Interactive Marketing, 15(1), 63-73.

3. Mattila, A.S., Mount, D.J., 2003, The impact of selected customer characteristics and response time on E-complaint satisfaction and return intent. Hospitality Management, 135-145.

4. Seth, N., Deshmukh, S.G., 2004. Indian Institute of Technology,Service Quality Models: a review. New Delhi, India, and Prem Vrat Indian Institute of Technology, Roorkee, India, Revised July 2004. International Journal of Quality \& Reliability Management, 22(9), 2005. 913-949. Emerald Group Publishing Ltd. 0265-671X,DOI10.1108/026567105106 25211.

5. Kulaklı, A., Birgün, S., 2005, Müşteri Merkezli Operasyonel Bilgi Yönetimi İçin Veri Yönetiminin Ölçülmesi, İTÜ İşletme Fakültesi, İşletme Mühendisliği Bölümü, 34357, Maçka, İstanbul, itüdergisi/bsosyal bilimler, 2(1), 37-48.

6. Demir, F.O., Kırdar, Y., 2012. Müşteri İlişkileri Yönetimi: CRM Review of Social, Economic \& Business Studies, 7(8), 293-308. (fbe.emu.edu.tr /journal/ doc/78/16.pdf.

7. Chan, J.O., 2005. Toward a Unified View of Customer Relationship Management. Journal of American Academy of Business, Cambridge; Mar 2005; 6(1); ABI/INFORM Complete. 32-38. 
8. Sharma, N.K, Drain, D., Cudney, E.A., Ragsdell, K.M., Paryani, K., 2008. Predicting Customer Expectation-Based Warranty Cost for Smaller The-Better and Larger- the-Better Performance Characteristics, 97-113.

9. Homburg,C., Fürst, A., Koschate, N., 2009. On the importance of complaint handling design: a multi level analysis of the impact in specific complaint situations. J. of the Acad. Mark. Sci. DOI .10.1007/s11747-009-0172- y. 1-51.

10. Henneberg, S.C., Thorsten G., Reppel, A., Ashnaib,B., Naude, P. 2009. Complaint management expectations: An Online Laddering analysis of small versus large firms. Industrial Marketing Management 38, 584-598.

11. Kayabaş1, A. 2010, Elektronik (online) Alışverişte Lojistik Faaliyetlere Yönelik. Müşteri Şikayetlerinin Analizi ve Bir Alan Araştırması Dumlupınar Üniversitesi, İşletme Araştırmaları Dergisi 2(2) (2010), 21-42.

12. Johnson, R., Mehra, S., 2002. Best-practice Complaint Management Academy ol Management Execuitive. 16(4), 1-7.

13. Davidow, M., 2003. University of Haifa, Organisational Responses to Customer Complaints: What Works and What Doesn't. Journal of Service Research, 5(3). February 2003 225-250 DOI: 10.1177/1094. 670502238917, 2003 Sage Publications.

14. Lee, C.H., Wang, Y.H., Trappey, A.J.C., 2014. Ontology-Based Reasoning for the Intelligent Handling of Customer Complaints. Computers \& Industrial Engineering, 84 (2015),144-155.

15. Faed, A., Chang, E., Saberki, M., Hussain, O.K., Azadeh, A., 2015. Intelligent Customer Complaint Handling Utilising Principal Component and Data Envelopment Analysis (PDA), Applied Soft Computing, G Model ASOC-2800; No. of Pages 17. Model for Customer Complaint Management Source: Marketing Science, Vol. 7, No. 3 (Summer), 287-298 (12),

16. Einwiller, S.A., Steilen, S., 2015, Handling Complaints on Social Network Sites. An Analysis of Complaints and Complaint Responses on Facebook and Twitter Pages of
Large US Companies. Public Relations Review 41 (2015), 195-204.

17. Liu, W.K., Yen, C.C., 2016. Optimizing Bus Passenger for Improved Public Sector Management.Sustainability 2016, 1319; 1-21

18. Strenitzerova, M., Gana, J., 2018, Customer Satisfaction and Loyalty as a Part of CustomerBased Corporate Sustainability in the Sector of Mobile Communications Services, Sustainability, 10(5), 1657.

19. İbiş, S., Kızıldemir, Ö., Çöp, S., 2019. Afyonkarahisar'da Faaliyet Gösteren Beş Yıldızlı Otel İşletmelerine Yönelik Yapılan Yorumların ve Şikayetlerin Değerlendirilmesi Elektronik Sosyal Bilimler Dergisi Temmuz (2019),18(7), ISSN: 1304-0278(1315-1324).

20. Bilir, N., Ergör, G., 2005, Saha Araştırmaları, Toraks Derneği Antalya File. toraks.org.tr/.../1513/O4QGBG64IKUZ70D. ppt Erişim tarihi:21.06.2012. 1-10.

21. Kalaycı, Ş., 2009. SPSS Uygulamalı Çok Değişkenli İstatistik Teknikleri, Editör: Doç. Dr. Şeref Kalaycı, 4. Baskı, Asil Yayın Dağıtım Ltd.Şti. 426 sayfa.

22. Shukla, P, University of Brighton, Correlation and regression, Marketing Research,http:// www.pauravshukla.com/marketing/researchmethods/correlationregression. pdf 1-31.

23. Aktürk, Z., Acemoğlu, H., 2011. Örnek Problemler ve SPSS Çözümleri, 330 sayfa http://www.aile.net/img/dosyaakturkzsaglik calisanlariicinpratikistatistik.pdfdokuman.

24. Fornell, C., Wernerfelt, B., 1988. A Model for Customer Complaint Managemnt Source: Marketing Science, 7(3). (Summer),287-298, Published by Informs.

25. Çekici, V. 2013. Müşteri Şikayet Değerlendirme Süreçleri İçin Kavramsal Bir Model ve Simülasyon Optimizasyon Yöntemi ile Değerlendirilmesi Çukurova Üniversitesi Fen Bilimleri Enstitüsü,Endüstri Mühendisliği Anabilim Dalı, Doktora Tezi, Kod no:1488, Adana-2013,247 sayfa, BAP No:MMF2011D1.

26. Berry, L., Parasuraman, A., 1997. Listening to the customer-The concept of a serviceQuality information System. Sloan Management Rewiew, 65-76. 